\title{
Caught in the Act: Live-Cell Imaging of Plant Meiosis
}

\author{
Maria Ada Prusicki, Martina Balboni, Kostika Sofronit, Yuki Hamamura and \\ Arp Schnittger*
}

Department of Developmental Biology, Institute for Plant Science and Microbiology, University of Hamburg, Hamburg, Germany

Live-cell imaging is a powerful method to obtain insights into cellular processes, particularly with respect to their dynamics. This is especially true for meiosis, where chromosomes and other cellular components such as the cytoskeleton follow an elaborate choreography over a relatively short period of time. Making these dynamics visible expands understanding of the regulation of meiosis and its underlying molecular

OPEN ACCESS

Edited by:

Christophe Lambing,

University of Cambridge,

United Kingdom

Reviewed by:

André Marques,

Max Planck Institute for Plant

Breeding Research, Germany Olivier Da Ines,

Université Clermont Auvergne, France

*Correspondence: Arp Schnittger

arp.schnittger@uni-hamburg.de

${ }^{\dagger}$ Present address: Kostika Sofroni,

Department of Meiosis, Max Planck Institute for Biophysical Chemistry,

Göttingen, Germany

Specialty section:

This article was submitted to Plant Cell Biology,

a section of the journal

Frontiers in Plant Science

Received: 31 May 2021 Accepted: 29 November 2021 Published: 21 December 2021

Citation:

Prusicki MA, Balboni M, Sofroni $K$, Hamamura Y and Schnittger A (2021)

Caught in the Act: Live-Cell Imaging of Plant Meiosis.

Front. Plant Sci. 12:718346. doi: 10.3389/fp/s.2021.718346 forces. However, the analysis of meiosis by live-cell imaging is challenging; specifically in plants, a temporally resolved understanding of chromosome segregation and recombination events is lacking. Recent advances in live-cell imaging now allow the analysis of meiotic events in plants in real time. These new microscopy methods rely on the generation of reporter lines for meiotic regulators and on the establishment of ex vivo culture and imaging conditions, which stabilize the specimen and keep it alive for several hours or even days. In this review, we combine an overview of the technical aspects of live-cell imaging in plants with a summary of outstanding questions that can now be addressed to promote live-cell imaging in Arabidopsis and other plant species and stimulate ideas on the topics that can be addressed in the context of plant meiotic recombination.

Keywords: chromosome, recombination, microscopy, cell division, culture media, fluorescent reporter, time course

\section{INTRODUCTION}

Meiosis is a specialized cell division process required for sexual reproduction. It consists of one round of DNA replication followed by two consecutive events of chromosome segregation that result in four genetically different cells with half the DNA content of the mother cell (e.g., haploid meiotic products are formed in diploid organisms). In animals, meiosis directly produces the gametes. By contrast, the meiotic products of plants, called spores, undergo several cell divisions, from just a few in vascular plants such as Arabidopsis (Arabidopsis thaliana) and maize (Zea mays) to many in non-vascular plants such as the moss Physcomitrium (Physcomitrella) patens and the genus Marchantia, to produce a gametophyte. The mature gametophyte harbors the actual gametes. In the case of flowering plants, including Arabidopsis and maize, the female gametophyte holds an egg cell and a central cell embedded in the embryo sac; the male gametophyte contains two sperm cells encapsulated in a pollen grain (Hater et al., 2020; Hafidh and Honys, 2021).

Some of the first observations of meiosis, dating from the late 19th century, were made by Oscar Hertwig, who studied sea urchins, and Eduard Van Beneden, who investigated the nematode Ascaris megalocephala (Hertwig, 1876; Van Beneden, 1883). Since then, microscopy has 
become a vital approach to investigate meiosis. In particular, cell spreads, immunostaining, and fluorescence in situ hybridization (FISH) analyses have been used to assemble the current extensive knowledge of meiosis (Keeney, 2009; Pradillo and Heckmann, 2020). These methods offer excellent spatial resolution, especially when subjected to super-resolution microscopy such as structured illumination microscopy (SIM), stimulated emission depletion (STED), and stochastic optical reconstruction microscopy (STORM), which have revealed the organization of the cohesin and synaptonemal complex (SC) in, for example, fruit fly (Drosophila melanogaster), the nematode Caenorhabditis elegans, mouse (Mus musculus), and recently Arabidopsis (Cahoon et al., 2017; Hernandez et al., 2018; Yoon et al., 2018; Xu et al., 2019; Sims et al., 2021).

However, as these techniques rely on fixed meiocytes, they give only a snapshot of the dynamic events taking place during the two cell divisions. Specifically, it is difficult to analyze meiotic progression in a heterogeneous population in which some cells behave differently from others: e.g., proceeding through meiosis at different paces and adopting different cellular configurations. Moreover, chromosome spreading procedures inherently rely on disrupting a higher-order three-dimensional structure and collapsing it onto a two-dimensional surface to make local chromatin details visible, such as the co-localization pattern of the recombinases DISRUPTED MEIOTIC cDNA1 (DMC1) and RADIATION51 (RAD51) (Reitz et al., 2019). In addition, the washing steps of immunolocalization experiments can also affect the pattern and abundance of biological structures and molecules, especially when they localize to the cytoplasm or nucleoplasm. On one hand, these washing steps can help enhance or reveal a specific localization pattern; for instance, the association of CYCLIN-DEPENDENT KINASE A;1 (CDKA;1) with chromatin in male meiotic cells in Arabidopsis only became visible after the nucleoplasmic fraction of CDKA;1 was reduced by the washing steps during immunolocalization experiments (Bulankova et al., 2010; Zhao et al., 2012; Yang et al., 2020). On the other hand, by changing the relative distribution of antigens, immunolocalization data deliver only a limited perspective of the situation found in nature. For instance, the abovementioned nucleoplasmic localization of CDKA;1 might in fact be biologically relevant. Moreover, not all epitopes are always accessible to an antibody, further decreasing the levels or aspects of the detected proteins.

Recent advances in microscopy, such as the improved lightgathering and detection sensitivity of laser scanning and spinning disk confocal microscope systems and the development of (lattice) light sheet microscopy, have made it possible to obtain cytological data in three and even four dimensions and to follow the course of meiosis in real time with little perturbation.

Early live-cell imaging studies of meiosis were conducted in fission yeast (Schizosaccharomyces pombe), budding yeast (Saccharomyces cerevisiae), and Drosophila in the 1990s (Chikashige et al., 1994; Smith et al., 1995; Matthies et al., 1996). The work in fission and budding yeasts was based on wide-field and fluorescence microscopy. Chikashige et al. (1994) monitored nuclear movements in fission yeast, attributing a leading function to the telomeres during the horse-tail configuration, which is a specific prophase stage characterized by parallel chromosome threads that extend longitudinally from one side of the nucleus to the other. Matthies et al. (1996) used a laser confocal scanning microscope (LCSM) to follow the dynamics of spindle assembly in Drosophila oocytes, which revealed that meiotic spindle formation in this organism does not depend on the presence of microtubule organizing centers, but rather is organized by the chromosomes.

Key questions in meiotic research regarding the mechanism, function, and regulation of chromosome pairing, telomere bouquet formation, $\mathrm{CO}$ formation, and spindle formation have since then been assessed by live-cell imaging, which has provided new insights. These studies included further analyses in fission yeast (Tomita and Cooper, 2007), budding yeast (Conrad et al., 2008; Koszul and Kleckner, 2009; Lee et al., 2012, 2020), and Drosophila (Hughes et al., 2011; Colombié et al., 2013; Christophorou et al., 2015), as well as C. elegans (Vargas et al., 2019), and mammalian cells (Schuh and Ellenberg, 2007; Kitajima et al., 2011; Holubcová et al., 2013; Lee et al., 2015; Pfender et al., 2015; Kyogoku and Kitajima, 2017; Mogessie and Schuh, 2017; Enguita-Marruedo et al., 2018; Nikalayevich et al., 2018; Silva et al., 2020; Wang et al., 2020).

An extensive discussion of the use of live-cell imaging of animal and yeast meiosis goes beyond the scope of this review. Therefore, we only highlight a few examples here that opened new research directions in meiosis and should stimulate equivalent lines of research in plants, as illustrated by the work of Kyogoku and Kitajima (2017) and Wang et al. (2020), in which the authors studied the biophysical regulation of meiosis, which is normally not accessible in fixed material. To this end, Kyogoku and Kitajima combined micromanipulation of cell size and cell shape with live-cell imaging. This work revealed that the large size of the oocyte correlates with errors in chromosome biorientation and with a less stringent spindle assembly checkpoint due to a low nucleus-to-cytoplasm ratio and therefore to the frequent aneuploidy of mammal oocytes (Kyogoku and Kitajima, 2017). Wang et al. (2020) succeeded in measuring the cytoplasmic stream and the underlying hydrodynamic forces generated, which correlated with the correct extrusion of the second polar body after meiosis II in mammalian oocytes.

Finally, live-cell imaging has been instrumental in performing new genetic screens (Pfender et al., 2015). Pfender et al. (2015) studied the function of 774 genes involved in meiosis using small interfering RNA (siRNA)-mediated silencing coupled with live-cell imaging. Groups of 12 siRNAs were injected into earlystage oocytes, which were still embedded into follicles, to induce knock-down phenotypes. Once the oocytes were fully grown, they were extruded and injected with mRNAs for GFP-a-tubulin (a-tubulin fused to the green fluorescent protein [GFP]) and $H 2 B-m R F P$ (histone H2B fused to the red fluorescent protein [RFP]) and incubated for $2-3 \mathrm{~h}$ to allow the translation of the fluorescent proteins before observation on a LCSM. Multiple cells were imaged in parallel, in four dimensions, as previously described (Schuh and Ellenberg, 2007). A manual evaluation of the phenotypes led to the description of 50 meiotic disturbances, including presence of lagging chromosomes, spindle length, or absence of nuclear envelope breakdown (NEB), which 
each corresponded to malfunctions of single genes, including previously unknown genes.

\section{LIVE-CELL IMAGING OF MEIOSIS IN PLANTS: TECHNICAL ASPECTS}

In contrast to animal and yeast systems, live-cell imaging in plants has not been a prominent technique to study meiosis in the past, with only a few articles presenting live-cell imaging data until recently (Yu et al., 1997; Sheehan and Pawlowski, 2009; Higgins et al., 2016; Nannas et al., 2016; Ingouff et al., 2017). This fact is surprising for several reasons. First, livecell imaging is extensively used to analyze various aspects of plant development and physiology, e.g., plant reproduction and the sensing of metabolites (Higashiyama et al., 2001; Okuda et al., 2009; Jones et al., 2014). Second, due to their large chromosomes and, hence, exquisite cell biology, many plant species (for instance, lily [Lilium sp.] and maize) are often used as model systems to study cell division, reaching as far back as one of the first optical description of mitosis by Strasburger (1888). One possible explanation for the lag in applying live-cell imaging to plant meiosis may stem from the challenges associated with directly observing plant meiocytes, as they are buried deep within reproductive tissues (Figure $\mathbf{1}$ ).

Recently, complementary experimental setups have been developed to overcome these shortcomings for the imaging of plant germ cells (Cromer et al., 2019; Prusicki et al., 2019; Valuchova et al., 2020). As these techniques are straightforward, they have the potential to be widely adopted in the plant meiosis field. One crucial consideration is to carefully evaluate how meiocytes can be reached and how they can be kept alive for long-term analyses spanning several hours.

\section{Sample Mounting and Medium Selection}

Plants are sensitive to environmental conditions, including temperature, osmolarity, and humidity (Buchanan et al., 2015). Therefore, it is crucial to apply proper environmental conditions when performing a live-cell imaging experiment and to choose an appropriate culture medium to maintain tissue viability without altering its development.

\section{Isolated Meiocytes}

Male meiocytes, or pollen mother cells (PMCs), develop within the anthers, are sustained by a layer of tapetum cells, and are protected by the middle layer, the endothecium, and the epidermis (Figure 1). Direct observations of isolated meiocytes require that immature flower buds to be collected and opened, and their anthers removed and excised at one end. Meiocytes are then extruded by gentle squeezing from the end distal from the cut and finally transferred onto the appropriate medium.

Early attempts to culture meiocytes were published in 1967 (Ito and Stern, 1967) studying meiotic division in vitro. Lily microsporocytes were cultured in a culture medium whose composition was based on White's solution (White, 1964) from zygotene through the meiotic progression (Ito and Stern, 1967; Table 1). Several challenges emerged from this first study in culturing isolated meiocytes. First, damage inflicted during meiocyte extraction severely affected the survival of the cells in vitro. Second, the success rate of meiocyte cell culture depended on the starting meiotic stage; meiocytes at early meiosis were delicate and suffered damage much more easily than older cells (Ito and Stern, 1967). This higher sensitivity might be related to intracellular connections among meiocytes and between meiocytes and tapetal cells, which appear to be very tight at early stages (Heslop-Harrison, 1966), resulting in rupture during dissection.

Nonetheless, meiocytes from various species of liliaceous plants have been successfully cultured since then (Stern and Hotta, 1970; Takegami et al., 1981; Ryan, 1983). Modifications to the composition of the original medium, such as the addition of microelements, known to increase cell survival, allowed the culturing of isolated meiocytes from rye (Secale cereale) (De La Peña, 1986; Rueda and Vázquez, 1988; Table 1).

However, while these plants have large enough chromosomes to be viewed using transmission light microscopy, none of these species is easily genetically tractable. Hence, adapting the methods implemented for the culture of lily and rye meiocytes to a system more amenable to genetic manipulation, such as maize, was an important advance to study the molecular mechanisms underlying meiosis in plants. Living maize meiocytes were successfully cultured and remained viable from pachytene to telophase II, and progression of meiosis and chromosome segregation was monitored for $24 \mathrm{~h}$ by epifluorescence microscopy (Chan and Zacheus Cande, 2000).

In addition to the specific composition of the culture medium, two environmental factors are crucial for culturing maize meiocytes: (1) the osmolarity of the medium, with an emphasis on sucrose concentration [the concentration range is very narrow for maize (0.28-0.34 M) (Chan and Zacheus Cande, 2000) but varies from plant to plant (Takegami et al., 1981)]; and (2) the temperature: maize meiocytes cannot be cultured at temperatures below $25^{\circ} \mathrm{C}$ without causing abnormal chromosome segregation (Yu et al., 1997).

Further experiments on isolated meiocytes have only been conducted in maize, following the same culturing principles based on White's solution (White, 1964), with a few adjustments (Table 1). For example, the sucrose concentration was lowered to $0.1 \mathrm{M}$ and the medium was supplemented with $0.1 \mathrm{M}$ maltose, $1 \%(\mathrm{v} / \mathrm{v})$ Guillard's antibiotic concentrated solution, and $0.25 \mathrm{mM}$ $n$-propyl gallate, known to increase the longevity of maize protoplasts in culture (Yu et al., 1997). Meiocytes extruded into this medium were viable for $9 \mathrm{~h}$ or longer and were observed undergoing meiosis II (Yu et al., 1997). The same medium was used to support growth of maize male meiocytes while imaging live meiosis I and meiosis II by fluorescence microscopy (Higgins et al., 2016; Nannas et al., 2016; Table 1).

\section{Dissected Anthers}

The first microscopy study of meiosis in intact and living plant anthers was performed in African lily (Agapanthus umbelatus) (Feijó and Cox, 2001). Freshly isolated anthers were incubated on a minimal medium (artificial pond water [APW]) that supported tissue viability without inducing major alterations in size or 


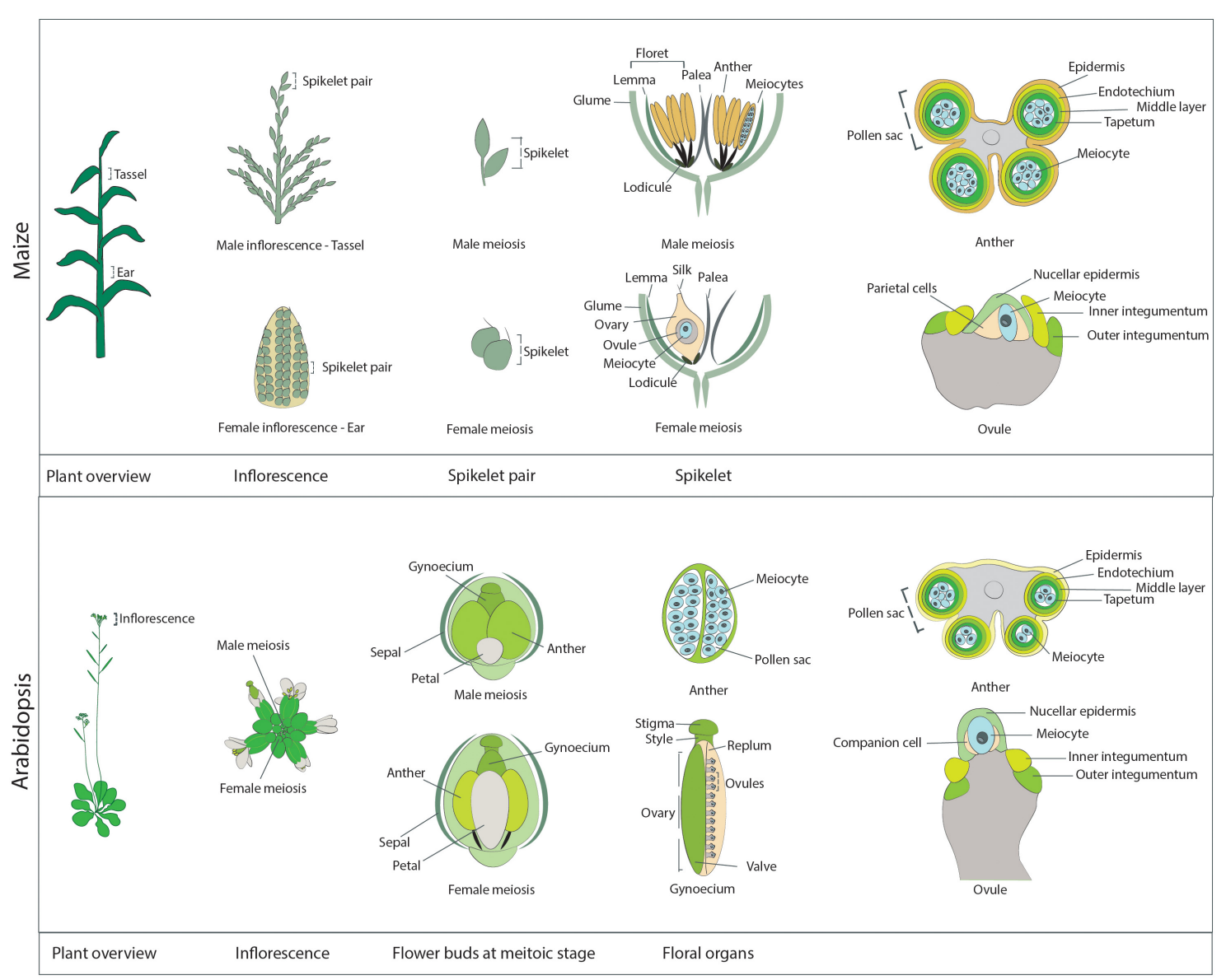

FIGURE 1 | Schematic overview of the reproductive structures harboring meiocytes in maize (upper panel) and Arabidopsis (lower panel). Maize: A maize plant at the meiotic stage. The immature male inflorescence, the tassel, is located at the last internode, while the immature female inflorescence, the ear, is positioned at the base of leaves in the midsection of the plant. The individual reproductive units of each inflorescence are the spikelets, which occur in pairs. Each spikelet comprises two florets, subtended by a pair of glumes. On the tassel, each floret contains a lemma, a palea, and three anthers, which harbor the male meiocytes. The maize anther at the meiotic stage is approximately $4 \mathrm{~mm}$ in length. As seen from the transverse section of an anther (right-most diagram), the meiocytes occupy the inner part of each of the four pollen sacs forming the anther and are surrounded by four cell layers: the tapetum, the middle layer, the endothecium, and the epidermis. A meiotic ear is approximately $20 \mathrm{~mm}$ in length. In each ear, only one of the two florets is functional, while the other floret degenerates. Each functional floret harbors the ovary, which contains one ovule enclosing the meiocyte and the parietal cells. The ovule structure at the meiotic stage is characterized by the presence of the inner and outer integuments, which elongate on each side of the nucellus. Arabidopsis: An Arabidopsis plant at the meiotic stage. Each inflorescence consists of multiple flower buds at different developmental stages. Each flower bud contains the male floral organs (six anthers) and the female floral organ (the gynoecium). These reproductive organs are surrounded by four petals and four sepals. Male meiosis takes place in flower buds when they are approximately $0.8 \mathrm{~mm}$ in length, are round in shape (not elongated), and contain very small petals that do not cover the anthers, which are approximately $0.2 \mathrm{~mm}$ in length. The transverse section of an Arabidopsis anther reveals a structure similar to that of maize anthers: The meiocytes occupy the inner part of each of the four pollen sacs, surrounded by the tapetum, the middle layer, the endothecium, and the epidermis. Female meiosis takes place in elongated flower buds that are approximately $1.2 \mathrm{~mm}$ in length (hence slightly later than male meiosis; at this stage anthers are elongated and start to get a yellow shade). The gynoecium, or pistil, reaches approximately $0.9 \mathrm{~mm}$ in length at the meiotic stage. It is composed of the stigma, the style, and the ovary, which contains multiple ovules, connected to the replum and protected by valves. As with maize, at the meiotic stage, primordia of the inner and outer integuments are visible rising on the side of the nucellus, while inside the nucellus it is possible to identify a single meiocyte and a pair of companion cells.

morphology for up to 3 days in culture (Feijó and Cox, 2001). APW is also an optically clear isotonic solution that causes minimal light scattering; moreover, APW is a minimal medium, i.e., without sugar, and is thus less likely to become contaminated with bacteria over long time-course experiments (Sheehan and Pawlowski, 2009; Table 1).

A similar approach was successfully implemented for imaging maize meiocytes; culturing them in a microscope slide chamber containing APW to examine chromosome dynamics during meiosis prophase I ensured a viability of over $30 \mathrm{~h}$ (Sheehan and Pawlowski, 2009). This approach allowed the application of chemicals, agents, or drugs such as cytoskeletondisrupting drugs (latrunculin and colchicine) and the observation of the resulting effects in living microspore mother cells (Sheehan and Pawlowski, 2009).

Imaging entire anthers offers the advantage of maintaining the developmental context of meiocytes, at least to some extent, thus limiting the influence of in vitro culturing on 
TABLE 1 | Composition of media used for live cell imaging of isolated meiocytes, dissected anthers and flower buds + depicts addition of, * modified concentration compared to the original medium cited, - depletion of.

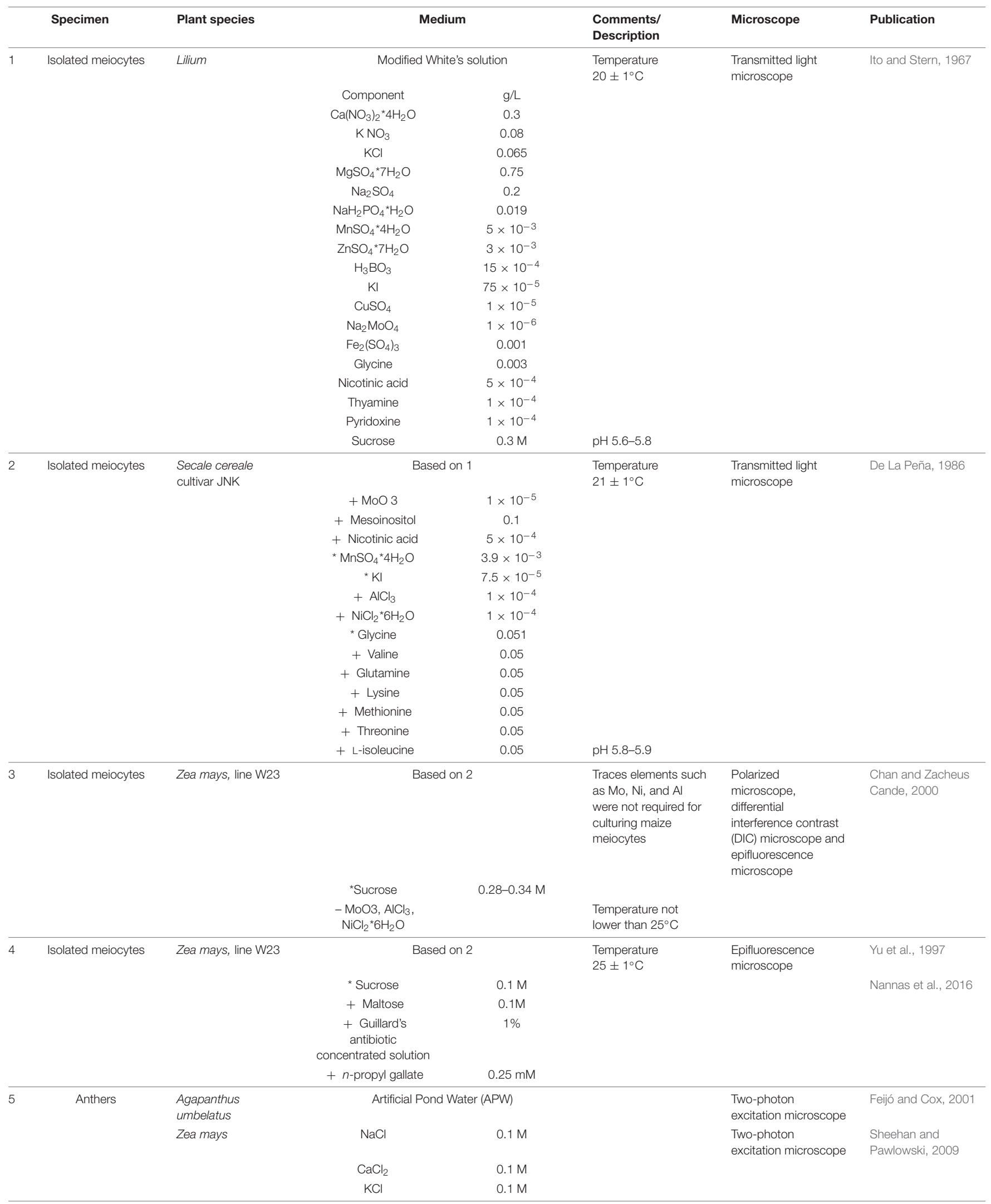


TABLE 1 | (Continued)

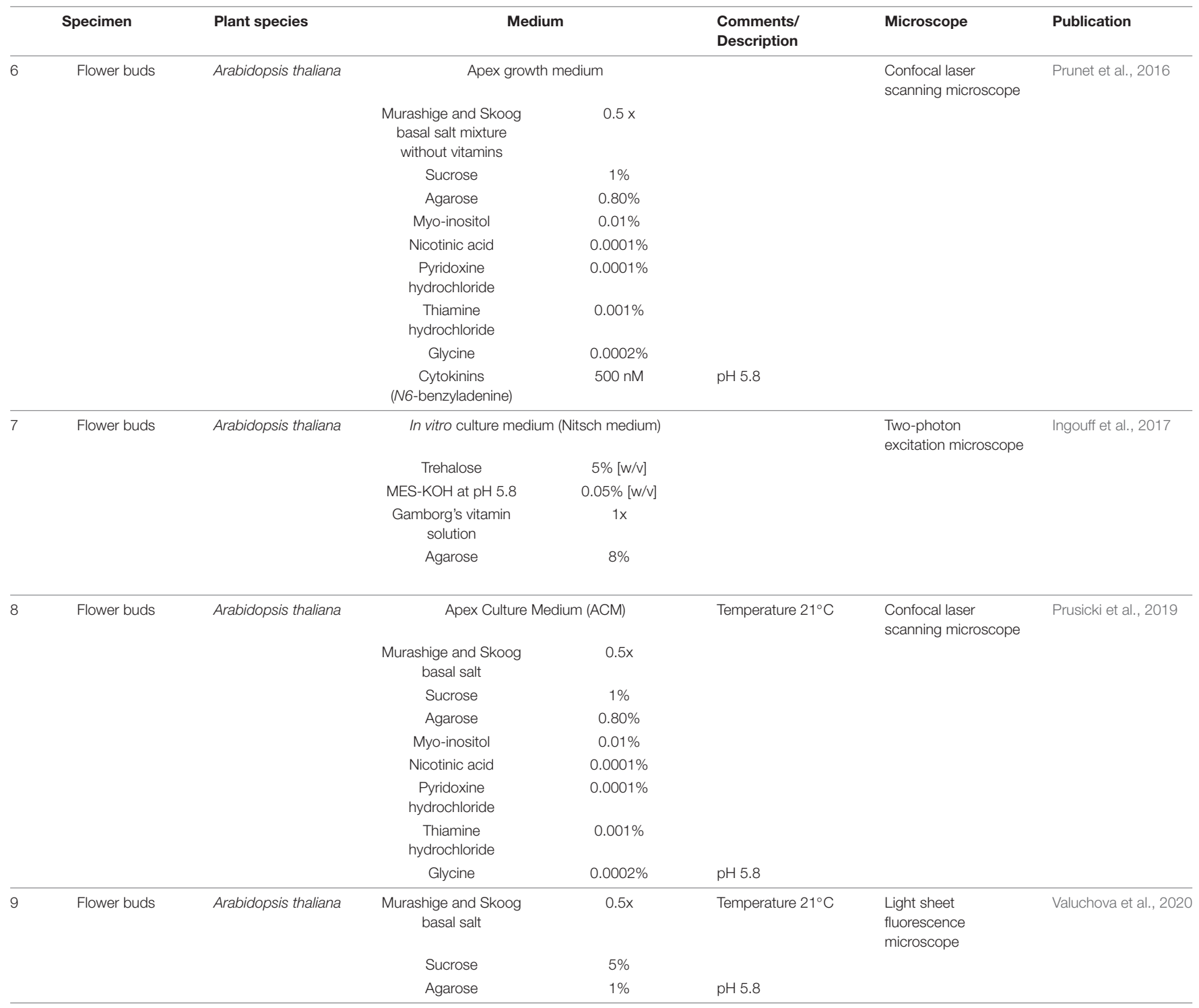

isolated meiocytes. Recently, this isolation method was applied to Arabidopsis; time-lapse movies of isolated anthers were recorded by a LCSM for over $4 \mathrm{~h}$ (Cromer et al., 2019). Flower buds were dissected, and undamaged anthers were transferred onto a slide topped by a spacer (0.12 $\mathrm{mm}$ deep) and filled with water as culturing medium. However, isolated anthers are fragile, especially at early stages when they contain meiocytes, and the dissection itself can easily stress and damage them, limiting the time span of live-cell imaging and raising the possibility that any observation reflects a stress reaction instead.

\section{Flower Buds}

As an alternative to isolated anthers, entire flower buds can be imaged, as recently established in Arabidopsis (Prusicki et al., 2019). Using entire flower buds is the least invasive ex vivo technique and thus further reduces the potential influence of sample handling before and during imaging. In the case of Arabidopsis, movies of living meiocytes of up to $30 \mathrm{~h}$ have been obtained (Prusicki et al., 2019).

This method is derived from the procedure previously applied for the observation of the development of emerging floral buds (Prunet et al., 2016; Table 1). Inflorescences are harvested, and all but one young flower primordium, which contains cells undergoing meiosis, are removed. The upper sepal is then removed to reveal two of the six anthers. Finally, the bud along with the pedicel and a few millimeters of the stem is embedded in Arabidopsis apex culture medium (ACM) (Table 1), kept in place with a drop of agarose, submerged in water, and imaged with an upright LCSM equipped with a water immersion objective (Prusicki et al., 2019, 2020a,b). Samples remain alive for up to 2 days with this method, allowing the analysis of the entire meiosis progression (Prusicki et al., 2019). This method also allows the addition of drugs 
such as oryzalin to the imaging medium; in the case of oryzalin, the effects induced by microtubule depolymerization can then be monitored in living meiocytes (Sofroni et al., 2020). Moreover, this imaging setup was also used to follow meiotic progression under heat stress, which was induced by using a heated incubation chamber surrounding the microscopic stage (De Jaeger-Braet et al., 2021).

Flower buds are also the starting material for an alternative approach of live-cell imaging for both the male and female germ cell lineage by light sheet fluorescence microscopy (LSFM) (Valuchova et al., 2020). The flower buds at a stage of interest are detached from inflorescences, and their sepals and petals are removed. To observe female meiosis, the anthers are excised, the stigma is cut off, and the valves are opened to expose the ovules attached to the septum. The dissected specimen is then embedded into capillaries containing medium with $1 \%$ (w/v) low-meltingpoint agarose (Valuchova et al., 2020; Table 1). Exploiting the fast image acquisition speed and the low phototoxicity and photobleaching of LSFM, long-term imaging sessions of up to 5 days are possible; three-dimensional images can also be acquired over time, allowing the introduction of a fourth dimension in the data.

While imaging entire flower buds is the method with the greatest potential, this approach is also limited in terms of specimen size. Imaging larger and/or more complex flower primordia than those of Arabidopsis, like maize, will require the development of other setups. Possible alternatives include a technique pioneered for live-cell imaging of methylation changes during Arabidopsis sporogenesis and gametogenesis. Here, the inflorescences are embedded in a solid in vitro culture medium (Nitsch medium), dissected with a vibratome, and observed by two-photon microscopy (Ingouff et al., 2017; Table 1).

\section{Reporter Lines}

A prerequisite for the study of cellular dynamics during meiosis is the labeling of cellular components (organelles, chromatin, microtubules, and others) so they can be visualized by chemical staining or by fluorescently labeled fusion proteins.

Chemical staining with the nucleic acid stains SYTO 12 and DAPI (4',6-diamidino-2-phenylindole) has been used to visualize isolated meiocytes or anthers in maize (Sheehan and Pawlowski, 2009; Higgins et al., 2016; Nannas et al., 2016). Chemical staining can be achieved on non-transgenic materials, which can be an advantage for plant species that cannot be transformed easily. However, the chemicals need to cross multiple cell layers before reaching and entering the meiocytes, making them more suited for imaging isolated cells. Protein chimeras, or fluorescent reporters, offer another route. They consist of a fusion between a fluorescent protein (FP) such as enhanced green fluorescent protein (EGFP), mVenus, or mCherry and the protein of interest. The transgenes encoding these fusions may be driven by the promoter of the gene of interest to minimize the potential for overexpression artifacts (Bastiaens and Pepperkok, 2000; DeBlasio et al., 2010). However, proteins with lower abundance might not be easily detectable during live-cell imaging; in these cases, highly active promoters like UBIQUITIN10 (UBQ10) or
RIBOSOMAL PROTEIN S5A (RPS5A) (Weijers et al., 2001) are sometimes preferred choices. Alternatively, tissue-specific promoters, like that of $D M C 1$, are employed when the promoter of interest is too weak or not well defined (Zhao et al., 2017). Typically, the FPs are added to the $\mathrm{N}$ or $\mathrm{C}$ terminus of the protein of interest; however, inserting the fluorescent tags along the protein might be necessary if a fusion to either terminus interferes with protein function, as it does in ZIPPER1 (ZYP1) (Yang et al., 2019).

Choosing the right FP is the first step in designing any livecell imaging assay. New FPs are constantly developed, and it is well advised to browse the literature for the latest advances in the field or check databases such as $I$ love GFP ${ }^{1}$. Ideal FPs for live-cell imaging are as bright and as photostable as possible. However, photostability will hinder fluorescence recovery after photobleaching (FRAP) experiments. Multimeric FPs, such as the tetrameric DsRed, are brighter but are likely to produce artifacts and/or interfere with protein function through forced dimerization or multimerization of the target protein. FPs should also be selected to allow the concomitant visualization of two or even three proteins at the same time. Often a GFP or yellow fluorescent protein (YFP) variant is combined with an RFP variant due to the adequate spectral separation of their excitation and emission spectra. When selecting the right FP, another consideration is that some proteins are excited with shorter wavelengths; for example, blue light is more toxic to the cell than longer wavelengths. However, the shorter the wavelength, the higher will be the spatial resolution due to the diffraction limit of microscopy. Another challenge in plant applications is the notorious autofluorescence of plant cells from chlorophyll, lignin, and flavonoids that may interfere with the detection of the fluorescent reporter of interest.

Photo-switchable and photo-activatable FPs have recently been applied to live-cell imaging in plants, expanding the palette of available reporters. One example is the monomeric fluorescent reporter EosFP, which is irreversibly converted from a green-emitting to a red-emitting protein upon exposure to ultraviolet light. When fused to proteins with multiple subcellular localizations, EosFP allows for a color-based differentiation between individual cells and organelle subpopulations and can be adapted to tracking subcellular structures and their interactions (Mathur et al., 2012). For instance, the 35Spro:H2B$m E o s F P$ reporter, expressing a fusion construct between histone $H 2 B$ and EosFP driven by the cauliflower mosaic virus (CaMV) 35S promoter, was transformed into tobacco (Nicotiana tabacum) and Arabidopsis plants to study endoreplication and changes in DNA content in living cells (Wozny et al., 2012). A second example is the photo-convertible monomeric protein Kikume Green-Red (mKikGR) variant, which was fused to HISTONE THREE RELATED10 (HTR10, with the reporter construct HTR10pro:HTR10-mKikGR) to study the dynamics of two identical sperm cells during fertilization in Arabidopsis (Hamamura et al., 2011).

Fluorescent reporters are not only useful as fusion proteins that inform on protein localization; they can also be designed to

\footnotetext{
${ }^{1}$ https://tlp.de/ypjk
} 
visualize and quantify the transcriptional response to a chemical stimulus, such as with the auxin reporter DR5:N7-mVenus (Table 2), used to indirectly visualize the distribution of the phytohormone during flower development (Valuchova et al., 2020). In this case, the fluorescent tag is not fused to another protein, but instead provides a visual read-out of the transcriptional activation of the synthetic $D R 5$ promoter by auxin (Valuchova et al., 2020).

\section{Chromosome and Chromatin Markers}

Meiosis-specific events including pairing, recombination, assembly, and disassembly of the SC take place in the nucleus. Dissecting their dynamics requires nuclear markers (reviewed in Wozny et al., 2012) and histone markers such as the histone H2A HTA10 and the histone H2B HTB9 (Valuchova et al., 2020) to highlight chromatin, as they are present throughout meiosis (Figure 2 and Table 2). The development of reporters encoding meiosis-specific proteins may also be needed. To date, several functional meiosis-specific reporter lines have been generated and used in live-cell imaging experiments or in vivo localization studies: markers for the cohesin complex (REC8 [RECOMBINATION8], SWI1 [SWITCHING DEFICIENT1], and WAPL [WINGS APART-LIKE]) (Figure 2 and Table 2; Prusicki et al., 2019; Yang et al., 2019) and markers for the chromosome axis, synaptonemal complex components, and their regulators ASYNAPTIC1 (ASY1), ASY3, ASY4, ZYP1b, PACHYTENE CHECKPOINT2 (PCH2), and COMET (Figure 2 and Table 2; Chambon et al., 2018; Yang et al., 2019, 2020; Balboni et al., 2020; Valuchova et al., 2020). These reporters have been instrumental in unraveling the dynamics of chromosomes in meiotic cells and in elucidating more complex cellular mechanisms, such as the prophase pathway of cohesin removal in plants and the regulation of the meiotic chromosome axis (Cromer et al., 2019; Yang et al., 2019, 2020; Balboni et al., 2020).

Centromeres are typically fluorescently tagged using CENTROMERIC HISTONE H3 (CENH3) and constitute a visual marker to determine gametophytic and somatic ploidy in Arabidopsis (De Storme et al., 2016; Liu et al., 2017). A maize YFP-tagged centromere line derived from the $\mathrm{ZmCENH3} \mathrm{cDNA}$ sequence (35Spro:CenH3:YFP) has been reported, but it has yet to be used in meiotic studies (Jin et al., 2008; Table 2). With respect to telomeres, live-cell CRISPR-Cas9-based imaging using EGFP or mRuby2 fused to the CRISPR-associated nuclease Cas9 allowed the visualization of telomeric regions in vivo in Nicotiana benthamiana leaves by harnessing the intrinsic ability of the nuclease to recognize palindromic repeats (Dreissig et al., 2017; Khosravi et al., 2020; Table 2). However, to date telomeres have not been successfully observed by live-cell imaging in any plant during meiosis.

Finally, levels and changes in DNA methylation during meiosis and gametophyte development in Arabidopsis are accessible via live-cell imaging of specific reporters for CG or non-CG methylation marks, such as HTR5pro:MBD-Venus (a fusion between a methyl-CpG-binding domain [MBD] and Venus under the control of the histone H3 HTR5 promoter) and HTR5pro:SUVH9-Venus (a fusion between
SU(VAR)3-9 HOMOLOG 9 and Venus), respectively (Table 2; Ingouff et al., 2017).

\section{Cytoskeletal Markers}

The microtubule cytoskeleton plays an essential role during cell divisions and undergoes dramatic changes over the course of meiosis. Therefore, fluorescent reporters for cytoskeletal elements provide important information on meiotic progression. A maize reporter line consisting of a fusion protein between the cyan fluorescent protein (CFP) and TUBULIN BETA, ECFPTUB (Table 2), was used to study spindle assembly (Higgins et al., 2016) and the positioning of the division plane during metaphase I and II (Nannas et al., 2016). Similar reporters were developed in Arabidopsis with TUBULIN alpha (TUA5) and TUBULIN beta (TUB4) fused to TagRFP (RPS5Apro:TagRFPTUB4 and RPS5Apro:TagRFP-TUA5) and driven by the RPS5A promoter (Figure 2 and Table 2). These reporters made it possible to describe the spatiotemporal dynamics of microtubule configurations during meiosis (Prusicki et al., 2019) and revealed microtubule dynamics anomalies in mutants with lower CDK activity such as tam (tardy asynchronous meiosis) or the cdka;1 $c d k d ; 3$ double mutant (Prusicki et al., 2019; Sofroni et al., 2020).

A GFP-tagged tubulin reporter driven by the UBIQUITIN14 promoter (UBQ14pro:GFP-TUA6) (Table 2) allowed the visualization of tubulin in fixed Arabidopsis anthers (Brownfield et al., 2015). Furthermore, motor proteins such as microtubuleassociated proteins (MAPs) are emerging as powerful reporters to characterize meiotic cytokinesis, as is the case of the reporter MAP65-3pro:GFP-MAP65-3 (Figure 2 and Table 2; Sofroni et al., 2020).

In contrast to microtubules, the regulation of actin filaments has not been extensively studied in plants, even though their relevance during cell division is well known (Rasmussen et al., 2013). FP-tagged Lifeact (Era et al., 2009), a yeast-derived actin-binding peptide, has provided a means to visualize actin filaments during pollen tube growth (Vogler and Sprunck, 2015; Liao and Weijers, 2018) and cell division (Wu and Bezanilla, 2014; Kimata et al., 2016). Of the naturally accumulating actinbinding proteins, only ACTIN RELATED PROTEIN6 (ARP6) fused to YFP was observed during meiosis, with a focus on ovules undergoing megasporogenesis (Qin et al., 2014; Table 2).

\section{Cell Cycle Reporters}

Markers able to differentiate phases of the cell cycle are very powerful tools when studying cell division and cell cycle progression (Echevarría et al., 2021). For example, reporters based on PROLIFERATING CELL NUCLEAR ANTIGEN1 (PCNA1) (PCNA1pro:PCNA1-sGFP and PCNA1pro:PCNA1TagRFP) allow distinction between pre-meiotic and early meiotic stages, as PCNA;1 accumulates in small speckles during early S-phase and in large foci in late S-phase, while it shows a diffuse localization throughout the nucleoplasm after S-phase (Figure 2 and Table 2; Yokoyama et al., 2016; Valuchova et al., 2020).

CDKs (in particular CDKA;1) and cyclins are among the main regulators of meiosis (Harashima et al., 2013, 2016; Wijnker and Schnittger, 2013), and several fluorescent reporters 
TABLE 2 | Fluorescent reporters expressed, or potentially expressed, in meiosis.

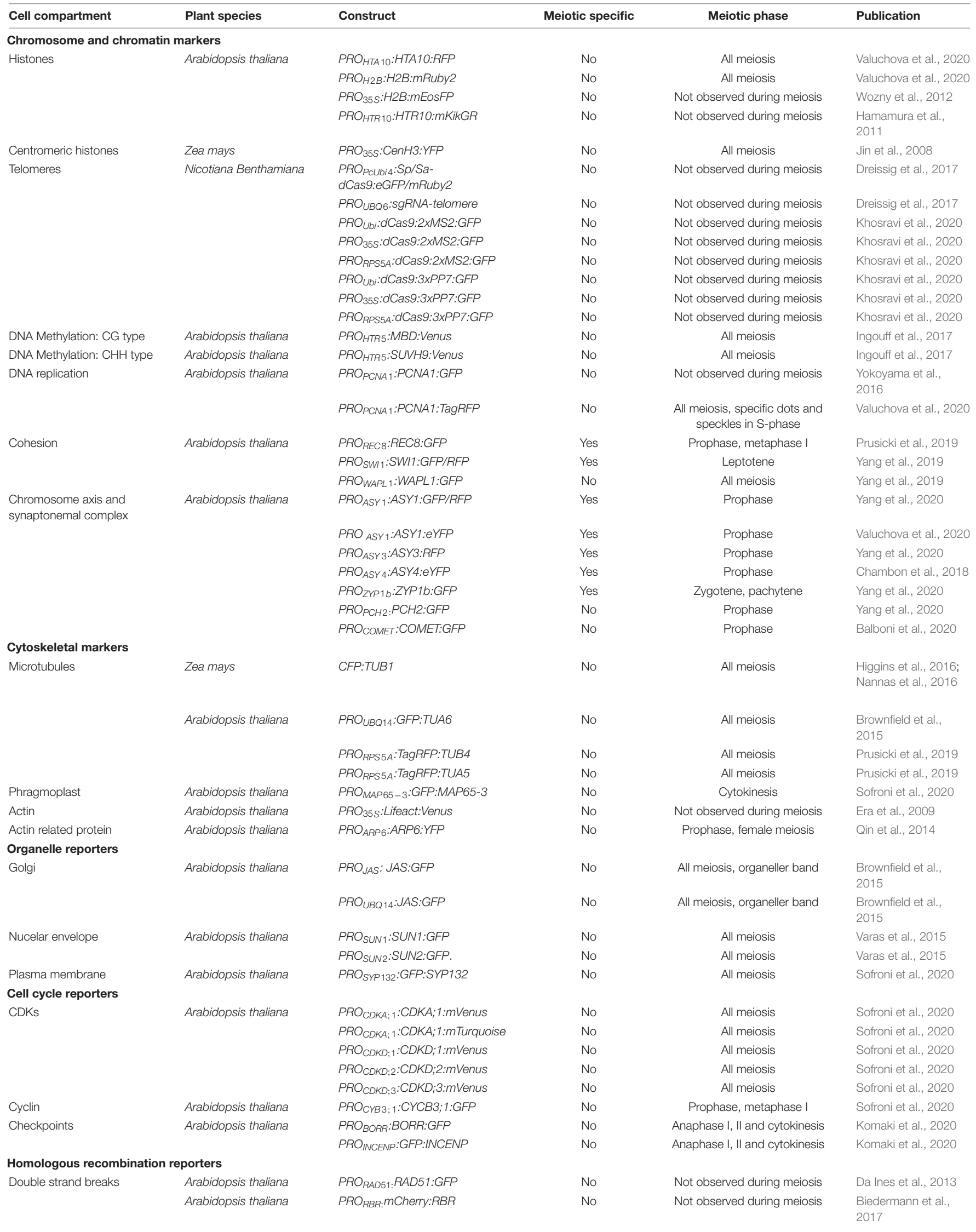




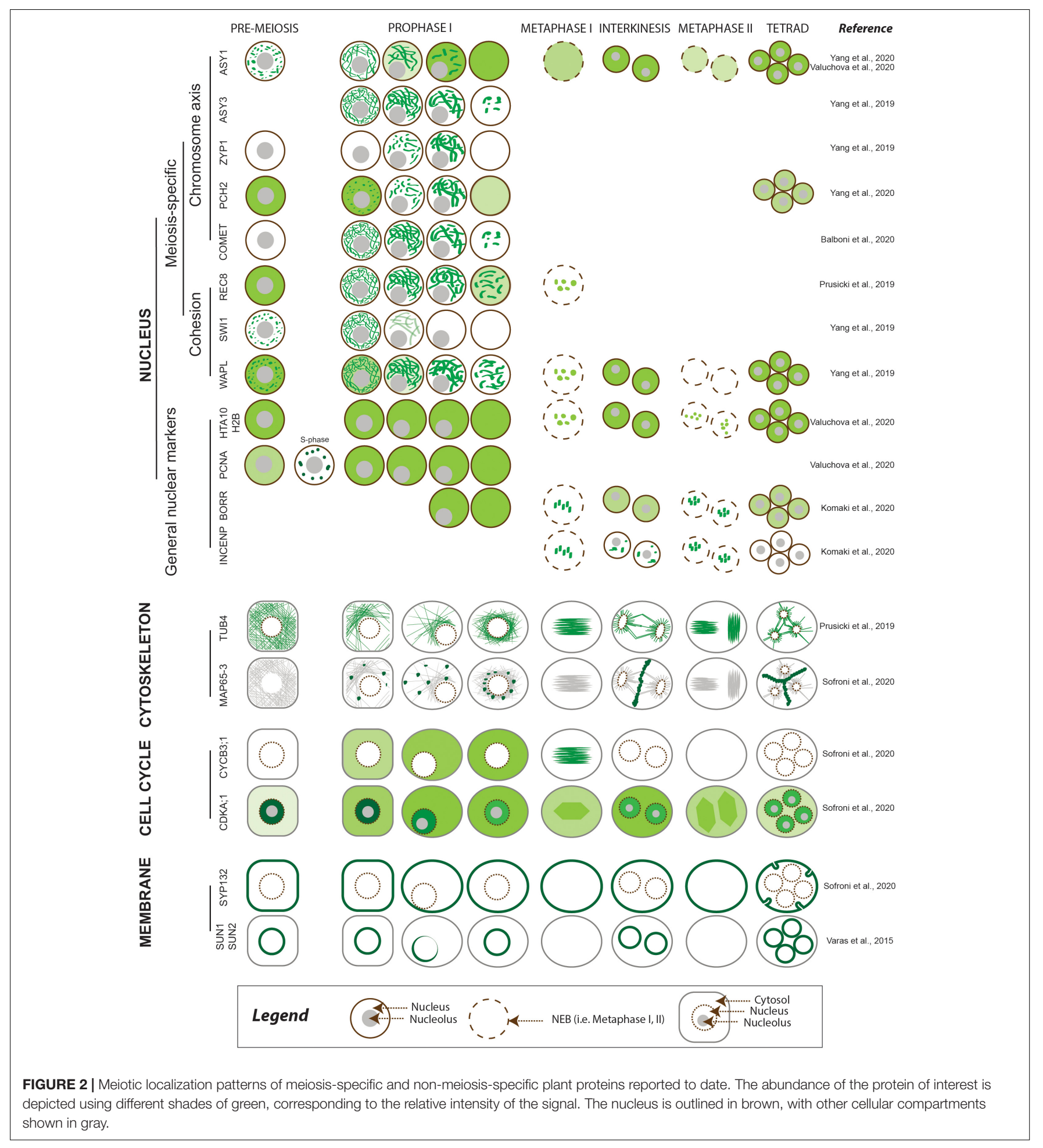

have already been developed to explore their dynamics. For example, the reporters CDKA1;1pro:CDKA;1-mVenus and CDKA1;1pro:CDKA;1-mTurquoise revealed the accumulation pattern of CDKA;1, which shows high abundance in the nucleus at early prophase, followed by a decrease at mid and late prophase, as reflected by the observed increase in fluorescence from the cytosol (Figure 2 and Table 2; Sofroni et al., 2020; Yang et al., 2020). Furthermore, the dynamics of CDKA;1 accumulation have been analyzed concomitantly with those of its regulators, such as CDK-activating kinases, which in Arabidopsis consist of cyclins like CYCB3;1 and D-type CDKs. CYCB3;1 exhibited a distinct association with the first meiotic spindle at 
metaphase I, making it a good reporter for the spindle (Sofroni et al., 2020; Figure 2 and Table 2).

Other cell cycle reporters are based on kinetochore components: the chromosome passenger complex (CPC) proteins BORRpro:BORR-GFP (encoding a fusion between the plant Borealin-like protein BOREALIN-RELATED and GFP) and INCENPpro:GFP-INCENP (for INNER CENTROMERE PROTEIN) are characterized by a highly dynamic localization pattern from nuclear envelope breakdown until the onset of anaphase (Komaki et al., 2020; Figure 2 and Table 2). Additional reporters for kinetochore components such as spindle assembly checkpoint (SAC) proteins are available and awaiting analysis during meiosis (Komaki and Schnittger, 2017). These reporters can also be used to study chromosome dynamics (see above).

\section{Membrane and Organellar Markers}

During meiotic progression, membranes and other compartments, e.g., the nuclear envelope, organelles, and phragmoplast components, play pivotal roles in chromosome pairing, spindle positioning, and successful cytokinesis (Murphy et al., 2014; Brownfield et al., 2015; Varas et al., 2015). Tracking membrane and organelle behavior in vivo thus has the potential to reveal interesting aspects of their function and regulation. To date, published work in this area of research is limited (Brownfield et al., 2015; Varas et al., 2015). Varas et al. (2015) visualized the nuclear envelope in Arabidopsis anthers using the fluorescent reporters SUN1pro:SUN1-GFP and SUN2pro:SUN2-GFP (Figure 2 and Table 2). SUN1 and SUN2 (for Sad1/UNC-84) are two components of the protein complex that form a bridge over the nuclear membrane and link elements from the nucleoplasm to the cytoskeleton (Varas et al., 2015). Brownfield et al. (2015) used the reporters JASpro:JAS-GFP and UBQ14pro:JAS-GFP (encoding a fusion protein between the unknown protein JASON [JAS] and GFP) (Table 2) to study the behavior of the organellar band, which forms after the first meiotic division. JAS was reported to localize to endomembrane vesicles involved in Golgi trafficking (Brownfield et al., 2015). Various FP-based reporters for the Golgi apparatus, the endoplasmic reticulum, peroxisomes, mitochondria, the plasma membrane, and the tonoplast have been introduced in Arabidopsis, tobacco, and rice but have yet to be analyzed during meiosis (Brownfield et al., 2015; Dangol et al., 2017; Ito et al., 2018). Finally, the SYP132pro:GFP-SYP132 reporter line (encoding GFP fused to SYNTAXIN OF PLANTS132 [SYP132]) was used to fluorescently label the plasma membrane in male meiocytes and revealed an outside-in direction of membrane invagination during male meiosis, whether cytokinesis was simultaneous or successive (Figure $\mathbf{2}$ and Table 2; Sofroni et al., 2020).

\section{Recombination Markers}

So far, very few reporters have been generated in plants to monitor recombination. The above-mentioned chromosome axis markers and reporters for the SC allow a broad temporal assignment of recombination processes based on previous annotation of each stage with immunolocalization techniques, for instance, labeling double-strand break (DSB) formation and localizing ASY1 to the axis roughly within a similar time window (Sanchez-Moran et al., 2007). Likewise, the reduction of HOMOLOG OF HUMAN HEI 10 (HEI10) foci from about 100 to around 10 in male meiosis is indicative of crossover (CO) formation and corresponds to the duration of the complete decoration of the chromosome axis by ASY1 to its partial removal from chromosome arms (Chelysheva et al., 2012). Moreover, the presence of the SC coincides with CO maturation, as visualized by the incorporation of the transverse filament component ZYP1.

However, a direct visualization of components of the recombination machinery has seldom been achieved. There is a lag in generating recombination reporters for proteins directly involved in DSB and CO formation and resolution such as SPORULATION11 (SPO11), DMCI1, HEI10, MutL HOMOLOG1 (MLH1), MutS HOMOLOG4 (MSH4), and MMS and UV SENSITIVE81 (MUS81); these proteins are instead extensively used in immunolocalization experiments in fixed samples. Although functional reporters for the Arabidopsis homologous recombination repair components RETINOBLASTOMA RELATED1 (RBR1) and RAD51 (RBR1pro:mCherry-RBR1 and RAD51pro:RAD51-GFP) are available (Chen et al., 2011; Da Ines et al., 2013; Biedermann et al., 2017), they have not yet been characterized or assessed for progression of meiotic recombination.

\section{ASPECTS OF PLANT MEIOSIS STUDIED BY LIVE-CELL IMAGING}

\section{Time Courses}

A change in meiotic duration, or in the duration of specific meiotic stages, is one of the main phenotypic alterations of plants exposed to suboptimal environmental conditions, such as high or low temperatures (reviewed in Bennett, 1971, 1977; Bomblies et al., 2015). Furthermore, the chronology of meiotic stages is often altered in meiotic mutants, such as in the maize mutant pam1 (plural abnormalities in meiosis1) (Golubovskaya et al., 2002) and the Arabidopsis tam (Magnard et al., 2001; Prusicki et al., 2019), msh4 (Higgins et al., 2004), mlh3 (Jackson et al., 2006), and pans1 $\Delta D$ (patronus1) mutants (Cromer et al., 2019) as well as plants expressing a dominant negative version of RAD51 (Singh et al., 2017). Accordingly, time courses of plant meiosis have been performed since the late 1960s using methods based on DNA labeling first with radioactive compounds (Ekberg and Eriksson, 1965; Lindgren et al., 1969; works from Bennett, reviewed in Bennett, 1971, 1977) and later with the modified thymine analogs 5-bromo-2'-deoxyuridine (BrdU) (Armstrong et al., 2003; Higgins et al., 2004; Jackson et al., 2006; Sanchez-Moran et al., 2007) and 5-ethynyl-2'-deoxyuridine (EdU) (Higgins et al., 2012; Stronghill et al., 2014; Varas et al., 2015; Singh et al., 2017) (an overview of time courses for plant meiosis in wild-type backgrounds is presented in Table 3).

In time-course experiments, the length of meiotic phases is determined by measuring the time between the labeling pulse (meiotic S-phase) and the appearance of marked chromosomes at specific stages. For instance, labeled chromosomes with a zygotene conformation are detected in Arabidopsis starting from 
TABLE 3 | Duration of meiosis in plants.

\section{MONOCOT}

\begin{tabular}{|c|c|c|c|c|c|c|c|c|c|c|c|c|c|c|c|c|c|c|c|}
\hline Plant species & Publication & Method & Temperature & $\begin{array}{c}\text { Overall } \\
\text { duration of } \\
\text { male meiosis }\end{array}$ & 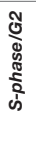 & 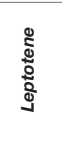 & 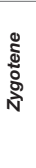 & 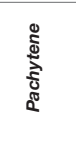 & 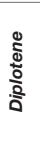 & 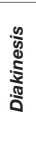 & 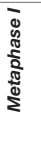 & 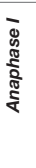 & 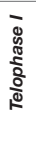 & 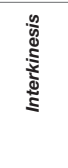 & $\begin{array}{l}= \\
\Phi \\
0 \\
\frac{8}{2} \\
\frac{0}{2} \\
0\end{array}$ & 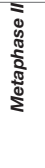 & 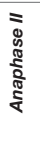 & 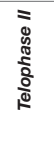 & है \\
\hline Allium cepa & Vasil, 1959 & $\begin{array}{l}\text { Aceto-carmine } \\
\text { staining }\end{array}$ & NOT GIVEN & $96 \mathrm{~h}$ & $/ /$ & $/ /$ & $/ /$ & $/ /$ & // & // & $/ /$ & $/ /$ & $/ /$ & // & $/ /$ & $/ /$ & // & $/ /$ & $/ /$ \\
\hline Convallaria majalis & $\begin{array}{l}\text { Reported in } \\
\text { Bennett, } 1977\end{array}$ & Not available & $20^{\circ} \mathrm{C}$ & $72 \mathrm{~h}$ & $/ /$ & $/ /$ & // & // & // & // & // & // & // & $/ /$ & // & $/ /$ & $/ /$ & // & $/ /$ \\
\hline \multirow[t]{7}{*}{$\begin{array}{l}\text { Dasypyrum } \\
\text { villosum }\end{array}$} & $\begin{array}{l}\text { Stefani and Colonna, } \\
1996\end{array}$ & $\begin{array}{l}\text { Aceto-orcein } \\
\text { staining }\end{array}$ & Field in May & $35 \pm 1.7 \mathrm{~h}$ & $/ /$ & & & $15.5 \mathrm{~h}$ & & & & & & $10.5 \mathrm{~h}$ & & & & $8 \mathrm{~h}$ & // \\
\hline & & & Field in July & $22 \pm 2 \mathrm{~h}$ & $/ /$ & & & $12 \mathrm{~h}$ & & & & & & $6 \mathrm{~h}$ & & & & $3.5 \mathrm{~h}$ & // \\
\hline & & & $5^{\circ} \mathrm{C}$ & $136 \pm 14.4 \mathrm{~h}$ & $/ /$ & & & $69.5 \mathrm{~h}$ & & & & & & $46 \mathrm{~h}$ & & & & $22 \mathrm{~h}$ & $/ /$ \\
\hline & & & $10^{\circ} \mathrm{C}$ & $88 \pm 5.3 \mathrm{~h}$ & // & & & $48 \mathrm{~h}$ & & & & & & $20.5 \mathrm{~h}$ & & & & $20 \mathrm{~h}$ & // \\
\hline & & & $20^{\circ} \mathrm{C}$ & $29 \mathrm{~h}$ & $/ /$ & & & $14 \mathrm{~h}$ & & & & & & $10 \mathrm{~h}$ & & & & $5 \mathrm{~h}$ & $/ /$ \\
\hline & & & $28^{\circ} \mathrm{C}$ & $21 \pm 0.7 \mathrm{~h}$ & $/ /$ & & & $12.5 \mathrm{~h}$ & & & & & & $5.5 \mathrm{~h}$ & & & & $4.5 \mathrm{~h}$ & $/ /$ \\
\hline & & & $35^{\circ} \mathrm{C}$ & $17 \pm 0.7 \mathrm{~h}$ & // & & & $10 \mathrm{~h}$ & & & & & & $5 \mathrm{~h}$ & & & & $3 \mathrm{~h}$ & // \\
\hline \multirow[t]{8}{*}{$\begin{array}{l}\text { Endymion } \\
\text { nonscriptus }\end{array}$} & Wilson, 1959 & $\begin{array}{l}\text { Aceto-carmine } \\
\text { staining }\end{array}$ & $0^{\circ} \mathrm{C}$ & $864 \mathrm{~h}$ & // & $/ /$ & // & $/ /$ & // & // & // & $/ /$ & // & $/ /$ & // & // & // & // & // \\
\hline & & & $5^{\circ} \mathrm{C}$ & $360 \mathrm{~h}$ & // & // & // & // & // & // & // & // & // & // & // & // & // & // & // \\
\hline & & & $10^{\circ} \mathrm{C}$ & $168 \mathrm{~h}$ & $/ /$ & $/ /$ & // & $/ /$ & // & $/ /$ & // & $/ /$ & $/ /$ & $/ /$ & // & $/ /$ & // & // & $/ /$ \\
\hline & & & $15^{\circ} \mathrm{C}$ & $84 \mathrm{~h}$ & $/ /$ & $/ /$ & // & $/ /$ & // & $/ /$ & $/ /$ & $/ /$ & $/ /$ & $/ /$ & $/ /$ & $/ /$ & $/ /$ & // & $/ /$ \\
\hline & & & $20^{\circ} \mathrm{C}$ & $48 \mathrm{~h}$ & $/ /$ & // & // & $/ /$ & // & // & // & // & // & $/ /$ & // & $/ /$ & // & $/ /$ & // \\
\hline & & & $25^{\circ} \mathrm{C}$ & $30 \mathrm{~h}$ & $/ /$ & $/ /$ & // & $/ /$ & // & $/ /$ & // & $/ /$ & $/ /$ & $/ /$ & // & $/ /$ & // & $/ /$ & $/ /$ \\
\hline & & & $30^{\circ} \mathrm{C}$ & $20 \mathrm{~h}$ & // & // & // & // & // & // & // & // & // & // & // & // & // & // & // \\
\hline & & & $15-21^{\circ} \mathrm{C}$ & $66 \mathrm{~h}$ & $/ /$ & // & // & // & // & // & // & // & // & // & // & // & // & $/ /$ & // \\
\hline Fritillaria meleagris & Barber, 1942 & $\begin{array}{l}\text { Acetocarmine } \\
\text { staining }\end{array}$ & $12-15^{\circ} \mathrm{C}$ & $\begin{array}{c}400 \mathrm{~h} \\
\text { APPROXIMATE }\end{array}$ & $/ /$ & // & // & // & $/ /$ & // & // & $/ /$ & // & $/ /$ & // & $/ /$ & $/ /$ & $/ /$ & $/ /$ \\
\hline Hordeum & Lindgren et al., 1969 & Aceto-orcein & NOT GIVEN & // & & $5.30 \%$ & & $32.60 \%$ & & & & & & $30 \%$ & & & & & $23.70 \%$ \\
\hline
\end{tabular}

vulgare:

Aceto-orcein

staining

unspecified variety

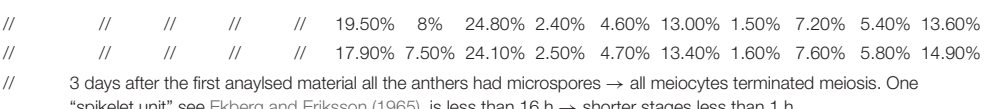

3 days after the first anaylsed material all the anthers had microspores $\rightarrow$ all meiocytes terminated meiosis. One

"spikelet unit" see Ekberg and Eriksson (1965), is less than $16 \mathrm{~h} \rightarrow$ shorter stages less than $1 \mathrm{~h}$

\begin{tabular}{|c|c|c|c|c|c|c|c|c|c|c|c|c|c|c|c|c|c|c|}
\hline $\begin{array}{l}\text { Hordeum } \\
\text { vulgare: Sultan }\end{array}$ & $\begin{array}{l}\text { Bennett and Finch, } \\
1971\end{array}$ & Feulgen staining & $20^{\circ} \mathrm{C}$ & $39.4 \mathrm{~h}$ & $/ /$ & $12 \mathrm{~h}$ & $9 \mathrm{~h}$ & $8.8 \mathrm{~h}$ & $2.2 \mathrm{~h}$ & $36 \mathrm{~min}$ & $1.6 \mathrm{~h}$ & $30 \mathrm{~min}$ & $30 \mathrm{~min}$ & dyad stage: $2 \mathrm{~h}$ & $1.2 \mathrm{~h}$ & $30 \mathrm{~min}$ & $30 \mathrm{~min}$ & $8 \mathrm{~h}$ \\
\hline $\begin{array}{l}\text { Hordeum } \\
\text { vulgare: Ymer }\end{array}$ & $\begin{array}{l}\text { Finch and Bennett, } \\
1972\end{array}$ & $\begin{array}{l}\text { Thymidine pulse + } \\
\text { autoradiography }\end{array}$ & $20^{\circ} \mathrm{C}$ & $39 \mathrm{~h}$ & // & $11.5 \mathrm{~h}$ & $9 \mathrm{~h}$ & $9.3 \mathrm{~h}$ & $1.9 \mathrm{~h}$ & $36 \mathrm{~min}$ & $1.6 \mathrm{~h}$ & $30 \mathrm{~min}$ & $30 \mathrm{~min} d$ & dyad stage: $1.7 \mathrm{~h}$ & $1.5 \mathrm{~h}$ & $30 \mathrm{~min}$ & $30 \mathrm{~min}$ & $>7 \mathrm{~h}$ \\
\hline $\begin{array}{l}\text { Hordeum } \\
\text { vulgare: Ymer } 4 \mathrm{X}\end{array}$ & $\begin{array}{l}\text { Finch and Bennett, } \\
1972\end{array}$ & $\begin{array}{l}\text { Thymidine pulse + } \\
\text { autoradiography }\end{array}$ & $20^{\circ} \mathrm{C}$ & $31 \mathrm{~h}$ & $/ /$ & $9 \mathrm{~h}$ & $7 \mathrm{~h}$ & $7 \mathrm{~h}$ & $1.8 \mathrm{~h}$ & $30 \mathrm{~min}$ & $1.5 \mathrm{~h}$ & $24 \min$ & $24 \min d$ & dyad stage: $1.5 \mathrm{~h}$ & $1 \mathrm{~h}$ & $24 \mathrm{~min}$ & $24 \mathrm{~min}$ & $>6 \mathrm{~h}$ \\
\hline \multirow[t]{2}{*}{$\begin{array}{l}\text { Hordeum } \\
\text { vulgare: Morex }\end{array}$} & Higgins et al., 2012 & $\begin{array}{l}\text { BrdU and EdU } \\
\text { labeling }\end{array}$ & $22^{\circ} \mathrm{C}$ & $43 \mathrm{~h}$ & $13 \mathrm{~h}$ & \multicolumn{13}{|c|}{$43 \mathrm{~h}$} \\
\hline & & & $30^{\circ} \mathrm{C}$ & $43 \mathrm{~h}$ & $9 \mathrm{~h}$ & \multicolumn{13}{|c|}{$43 \mathrm{~h}$} \\
\hline $\begin{array}{l}\text { Lilium } \\
\text { candidum }\end{array}$ & $\begin{array}{l}\text { Reported in } \\
\text { Bennett, } 1977\end{array}$ & Not available & NOT GIVEN & $168 \mathrm{~h}$ & /1 & $1 /$ & /1 & /1 & // & /I & /1 & /1 & // & // & /I & /1 & /1 & /I \\
\hline $\begin{array}{l}\text { Lilium } \\
\text { henryi }\end{array}$ & $\begin{array}{l}\text { Reported in } \\
\text { Bennett, } 1977\end{array}$ & Not available & NOT GIVEN & $170 \mathrm{~h}$ & /1 & /I & // & /1 & /1 & /1 & $1 /$ & // & // & // & // & // & /I & /1 \\
\hline $\begin{array}{l}\text { Lilium } \\
\text { hybrid: Black Beuty }\end{array}$ & Bennett et al., 1975 & Fuchsin staining & $20^{\circ} \mathrm{C}$ & $264 \mathrm{~h}$ & // & $/ /$ & // & /1 & // & // & /1 & // & // & // & /1 & // & /1 & $/ /$ \\
\hline $\begin{array}{l}\text { Lilium } \\
\text { hybrid: Sonata }\end{array}$ & Bennett et al., 1975 & Fuchsin staining & $20^{\circ} \mathrm{C}$ & $180 \mathrm{~h}$ & /I & /1 & // & /I & /1 & /I & /1 & /I & // & // & /I & /I & /1 & /1 \\
\hline $\begin{array}{l}\text { Lilium longiflorum: variety } \\
\text { unspecified }\end{array}$ & Marquardt, 1937 & $\begin{array}{l}\text { Aceto-carmine } \\
\text { staining }\end{array}$ & NOT GIVEN & $96 \mathrm{~h}$ & /1 & /I & $/ /$ & // & /1 & // & // & /I & // & /I & // & // & // & // \\
\hline $\begin{array}{l}\text { Lilium longiflorum: Nellie } \\
\text { White }\end{array}$ & Ito and Stern, 1967 & Autoradiography & $22^{\circ} \mathrm{C}$ & ca192 h & /1 & /I & // & // & /1 & /1 & $1 /$ & // & // & // & // & // & /I & /1 \\
\hline Lilium longiflorum: Croft & $\begin{array}{l}\text { Taylor and McMaster, } \\
1953\end{array}$ & Autoradiography & $23^{\circ} \mathrm{C}$ & ca192h & /1 & /1 & /1 & /1 & /1 & /1 & /1 & /1 & /1 & // & /I & /1 & /1 & /1 \\
\hline Lilium longiflorum: Floridii & Erickson, 1948 & $\begin{array}{l}\text { Aceto-orcein } \\
\text { staining }\end{array}$ & NOT GIVEN & ca240h & /I & /1 & // & /I & /1 & /I & /1 & /1 & /I & // & /I & // & /1 & /1 \\
\hline Ornithogalum virens & $\begin{array}{l}\text { Church and Wimber, } \\
1969\end{array}$ & $\begin{array}{l}\text { Thymidine pulse + } \\
\text { autoradiography }\end{array}$ & $18^{\circ} \mathrm{C}$ & $\begin{array}{c}72 \mathrm{~h}- \\
\text { APPROXIMATE }\end{array}$ & /1 & $1 /$ & /1 & /1 & // & /1 & /1 & /1 & // & // & /I & /1 & /1 & // \\
\hline \multirow[t]{3}{*}{ Secale cereale } & $\begin{array}{l}\text { Bennett et al., 1971, } \\
\text { 1972; Bennett and } \\
\text { Smith, } 1972\end{array}$ & Feulgen staining & $15^{\circ} \mathrm{C}$ & $88 \mathrm{~h}$ & /1 & // & // & // & /1 & /1 & $1 /$ & // & // & $/ /$ & // & // & /I & /1 \\
\hline & & & $20^{\circ} \mathrm{C}$ & $51 \mathrm{~h}$ & // & $20 \mathrm{~h}$ & $11.4 \mathrm{~h}$ & $8 \mathrm{~h}$ & $1 \mathrm{~h}$ & $36 \mathrm{~min}$ & $2 \mathrm{~h}$ & $1 \mathrm{~h}$ & $1 \mathrm{~h}$ & dyads: $2.5 \mathrm{~h}$ & $1.7 \mathrm{~h}$ & $1 \mathrm{~h}$ & $1 \mathrm{~h}$ & $/ /$ \\
\hline & & & $25^{\circ} \mathrm{C}$ & $39 \mathrm{~h}$ & // & $/ /$ & // & // & // & // & // & // & // & // $\quad / /$ & // & // & // & // \\
\hline Secale cereale $4 X$ & $\begin{array}{l}\text { Bennett and Smith, } \\
1972\end{array}$ & Feulgen staining & $20^{\circ} \mathrm{C}$ & $38 \mathrm{~h}$ & $/ /$ & $13 \mathrm{~h}$ & $9 \mathrm{~h}$ & $6.4 \mathrm{~h}$ & $1 \mathrm{~h}$ & $36 \mathrm{~min}$ & $1.8 \mathrm{~h}$ & $42 \mathrm{~min}$ & $42 \mathrm{~min}$ & dyad stage: $2 \mathrm{~h}$ & $1.4 \mathrm{~h}$ & $42 \mathrm{~min}$ & $42 \mathrm{~min}$ & $/ /$ \\
\hline Tradescantia paludosa & $\begin{array}{l}\text { Reported in Bennett, } \\
1977\end{array}$ & Not available & NOT GIVEN & $126 \mathrm{~h}$ & $/ /$ & $/ /$ & $/ /$ & $/ /$ & /1 & $/ /$ & /1 & $/ /$ & /1 & $/ /$ & // & // & /1 & $/ /$ \\
\hline Tradescantia reflexa & $\begin{array}{l}\text { Reported in Bennett, } \\
1977\end{array}$ & Not available & NOT GIVEN & 144 hs & // & $/ /$ & $/ /$ & /1 & /1 & // & /1 & // & // & // & // & // & // & $/ /$ \\
\hline \multirow[t]{4}{*}{ Trillium erectum } & Hotta and Stern, 1963 & Autoradiography & $1^{\circ} \mathrm{C}$ & $2160 \mathrm{~h}$ & /I & /1 & // & /1 & /1 & /1 & 11 & /1 & // & // & // & // & /1 & /1 \\
\hline & Hotta and Stern, 1963 & Autoradiography & $2^{\circ} \mathrm{C}$ & $1680 \mathrm{~h}$ & // & // & // & // & // & // & // & // & // & // & // & // & // & // \\
\hline & Kemp, 1964 & Propronio-carmine & $5^{\circ} \mathrm{C}$ & $960 \mathrm{~h}$ & $/ /$ & // & $/ /$ & // & // & // & // & // & // & $/ /$ & $/ /$ & // & // & // \\
\hline & Ito and Stern, 1967 & Autoradiography & $15^{\circ} \mathrm{C}$ & $288 \mathrm{~h}$ & /I & // & // & // & // & // & // & // & // & // & // & // & // & // \\
\hline
\end{tabular}


TABLE 3 | (Continued)

\section{MONOCOT}

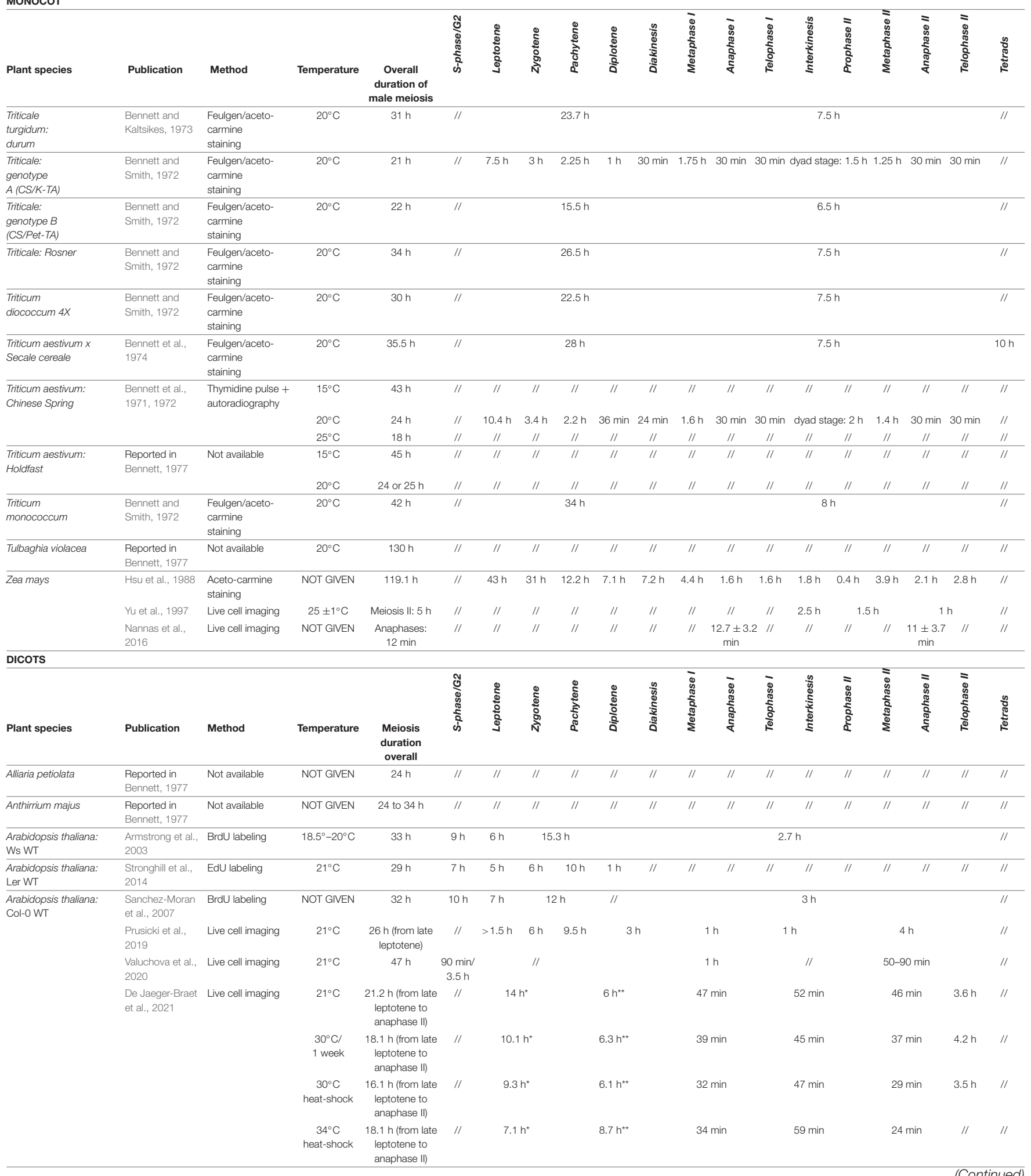


TABLE 3 | (Continued)

DICOTS

\begin{tabular}{|c|c|c|c|c|c|c|c|c|c|c|c|c|c|c|c|c|c|c|c|}
\hline Plant species & Publication & Method & Temperature & $\begin{array}{c}\text { Overall } \\
\text { duration of } \\
\text { male meiosis }\end{array}$ & 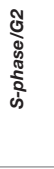 & 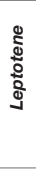 & 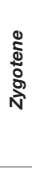 & 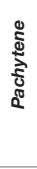 & $\begin{array}{l}\frac{1}{0} \\
\frac{0}{0} \\
\frac{0}{0}\end{array}$ & 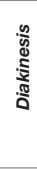 & 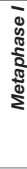 & 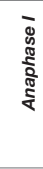 & 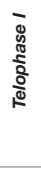 & 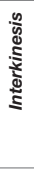 & $\begin{array}{l}= \\
0 \\
0 \\
\frac{1}{0} \\
\vdots \\
0 \\
0\end{array}$ & 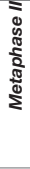 & 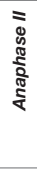 & 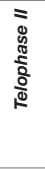 & 宽 \\
\hline Beta vulgaris & $\begin{array}{l}\text { Reported in } \\
\text { Bennett, } 1977\end{array}$ & Not available & $20^{\circ} \mathrm{C}$ & $24 \mathrm{~h}$ & $/ /$ & $/ /$ & // & $/ /$ & /1 & // & $/ /$ & // & $/ /$ & // & /1 & $/ /$ & $/ /$ & $/ /$ & $/ /$ \\
\hline $\begin{array}{l}\text { Capsella } \\
\text { bursa-pastoris }\end{array}$ & $\begin{array}{l}\text { Reported in } \\
\text { Bennett, } 1977\end{array}$ & Not available & NOT GIVEN & $18 \mathrm{~h}$ & $/ /$ & $/ /$ & $/ /$ & /1 & // & $/ /$ & // & // & $/ /$ & $/ /$ & /1 & $/ /$ & // & // & $/ /$ \\
\hline $\begin{array}{l}\text { Haplopappus } \\
\text { gracilis }\end{array}$ & $\begin{array}{l}\text { Reported in } \\
\text { Bennett, } 1977\end{array}$ & Not available & NOT GIVEN & $24-36 \mathrm{~h}$ & $/ /$ & $/ /$ & // & /1 & /1 & $/ /$ & $/ /$ & // & $/ /$ & // & /I & $/ /$ & $/ /$ & $/ /$ & $/ /$ \\
\hline $\begin{array}{l}\text { Lycopersicum } \\
\text { esculentum } \\
\text { (Solanum } \\
\text { lycopersicum) }\end{array}$ & $\begin{array}{l}\text { Reported in } \\
\text { Bennett, } 1977\end{array}$ & Not available & $20^{\circ} \mathrm{C}$ & $24-30 \mathrm{~h}$ & $/ /$ & $/ /$ & // & // & // & // & // & // & $/ /$ & $/ /$ & /1 & // & /1 & // & $/ /$ \\
\hline $\begin{array}{l}\text { Lycopersicum } \\
\text { peruvianum }\end{array}$ & $\begin{array}{l}\text { Pacini and Cresti, } \\
1978\end{array}$ & $\begin{array}{l}\text { Uranyl acetate } \\
\text { staining }\end{array}$ & NOT GIVEN & Prophase $12 \mathrm{~h}$ & $/ /$ & & \multicolumn{2}{|c|}{$12 \mathrm{~h}$} & & & $/ /$ & // & $/ /$ & // & /1 & $/ /$ & /1 & $/ /$ & $/ /$ \\
\hline Petunia hybrida & $\begin{array}{l}\text { Izhar and Frankel, } \\
1973\end{array}$ & $\begin{array}{l}\text { Fixed anthers/ } \\
\text { staining not } \\
\text { specified }\end{array}$ & $\begin{array}{l}15-17^{\circ} \mathrm{C} \text { night } \\
/ 25-30^{\circ} \mathrm{C} \text { day }\end{array}$ & $16 \mathrm{~h}$ & \multicolumn{2}{|c|}{$4 \mathrm{~h}$} & $2 \mathrm{~h}$ & $2 \mathrm{~h}$ & \multicolumn{2}{|c|}{$1 \mathrm{~h}$} & \multicolumn{2}{|c|}{$2 \mathrm{~h}$} & $1 \mathrm{~h}$ & & \multicolumn{2}{|c|}{$1 \mathrm{~h}$} & & $3 \mathrm{~h}$ & $12 \mathrm{~h}$ \\
\hline Pisum sativum & $\begin{array}{l}\text { Reported in } \\
\text { Bennett, } 1977\end{array}$ & Not available & $20^{\circ} \mathrm{C}$ & $30 \mathrm{~h}$ & $/ /$ & $/ /$ & // & // & /I & // & // & /1 & $/ /$ & // & // & // & /I & // & $/ /$ \\
\hline Veronica chamaedrys & $\begin{array}{l}\text { Reported in } \\
\text { Bennett, } 1977\end{array}$ & Not available & NOT GIVEN & $20 \mathrm{~h}$ & // & /1 & // & /I & /I & // & /I & /I & // & // & "I & // & // & // & // \\
\hline Vicia faba & $\begin{array}{l}\text { Reported in } \\
\text { Bennett, } 1977\end{array}$ & Not available & NOT GIVEN & 72 to $96 \mathrm{~h}$ & $/ /$ & $/ /$ & // & /I & /I & // & // & /1 & // & // & /I & // & /1 & // & $/ /$ \\
\hline Vicia sativa & $\begin{array}{l}\text { Reported in } \\
\text { Bennett, } 1977\end{array}$ & Not available & $20^{\circ} \mathrm{C}$ & $24 \mathrm{~h}$ & // & // & // & // & /I & // & // & /I & // & // & /I & // & // & // & // \\
\hline \multicolumn{20}{|l|}{ GYMNOSPERM } \\
\hline Pinus laricio & $\begin{array}{l}\text { Chamberlain, } 1935 \\
\text { (Reported in } \\
\text { Izhar and Frankel, } \\
\text { 1973) }\end{array}$ & Not available & NOT GIVEN & 3 months & $/ /$ & // & // & /1 & // & // & // & /1 & $/ /$ & // & /1 & // & $/ /$ & // & $/ /$ \\
\hline
\end{tabular}

// depicts not calculated or not specified data,

* inlcudes early pachytene,

** includes only late pachytene - diplotene.

$18 \mathrm{~h}$ after a pulse, while it takes $30 \mathrm{~h}$ after a pulse to label chromosomes from diakinesis to telophase II, indicating that the zygotene-pachytene interval lasts for about $12 \mathrm{~h}$ in Arabidopsis (Sanchez-Moran et al., 2007).

However, this method is laborious and relies on the efficiency of chromosome spreads in combination with immunocytochemistry. Thus, sample sizes are typically small and preclude a quantitative analysis of the resulting data. For the same reason, it is also difficult to obtain reliable estimates for heterogeneous cell populations, as for example in the tam mutant background. Likewise, short phases, such a meiosis II, which lasts approximately $3 \mathrm{~h}$ in Arabidopsis, are difficult to analyze with this method (Armstrong et al., 2003; Sanchez-Moran et al., 2007; Stronghill et al., 2014).

By contrast, live-cell imaging techniques allow the direct observation of individual cells while they undergo meiosis. Moreover, at least in the case of male meiocytes, several samples can be analyzed in one scan, making it possible, though still tedious, to obtain statistically robust sample sizes by scanning several anthers. The first dataset to temporally resolve meiotic phases by live-cell imaging was collected on maize meiocytes observed from metaphase I to telophase II (prometaphase Imetaphase I, up to $60 \mathrm{~min}$; anaphase I, up to $30 \mathrm{~min}$; interkinesis, up to $150 \mathrm{~min}$; prometaphase II-metaphase II, up to $90 \mathrm{~min}$; anaphase II/telophase II, up to $60 \mathrm{~min}$ ) (Table 3; Yu et al., 1997, 1999). Likewise, it was possible to determine the duration of these phases in Arabidopsis from zygotene onward (zygotene, $6 \mathrm{~h}$; pachytene, $9.5 \mathrm{~h}$; diplotene and diakinesis, $3 \mathrm{~h}$; metaphase I and anaphase I, $1 \mathrm{~h}$; telophase and interkinesis, $1 \mathrm{~h}$; second meiotic division, 4 h) (Table 3; Prusicki et al., 2019).

In Arabidopsis, meiotic time courses measured by live-cell imaging recapitulate the results obtained by pulse labeling experiments for an overall duration of meiosis of about $26 \mathrm{~h}$ (Table 3; Prusicki et al., 2019). Live-cell imaging revealed then that an increase of the ambient temperature to $30^{\circ} \mathrm{C}$ resulted in an acceleration of most but not all meiotic phases in Arabidopsis (De Jaeger-Braet et al., 2021). For instance, the duration of metaphase I to anaphase I was shortened from nearly $1 \mathrm{~h}$ to approximately $0.5 \mathrm{~h}$ at $30^{\circ} \mathrm{C}$. An additional temperature raise to $34^{\circ} \mathrm{C}$ sped up specific phases of meiosis even further, e.g., late leptotene to early pachytene lasted approximately $14 \mathrm{~h}$ at $21^{\circ} \mathrm{C}, 9 \mathrm{~h}$ at $30^{\circ} \mathrm{C}$ and only $7 \mathrm{~h}$ at $34^{\circ} \mathrm{C}$. At $34^{\circ} \mathrm{C}$, however, pachytene to diakinesis was considerably delayed from $6 \mathrm{~h}$ at $21^{\circ} \mathrm{C}$ and $30^{\circ} \mathrm{C}$ to almost $9 \mathrm{~h}$ at $34^{\circ} \mathrm{C}$. This delay, together with genetic and cell biological data, indicated the presence of a recombination checkpoint in plants (see below) (De Jaeger-Braet et al., 2021).

Obviously, the choice of reporters will limit the amount of information retrieved. In the case of the time course published by Prusicki et al. (2019), the use of REC8 and TUBULIN as cellular markers offered sufficient cellular criteria (morphological resolution) to dissect meiosis from prophase I until telophase II, although it was not possible to calculate the timing of S-phase or G2 phase, or the exact moment of meiosis onset. To obtain information on these early phases, Valuchova et al. (2020) used the PCNA-TagRFP reporter, which allowed the determination of the lengths of late S-phase and G2 phase to be $90 \mathrm{~min}$ 
and $3.5 \mathrm{~h}$, respectively, much shorter durations than previously estimated (Table 3).

Live-cell imaging can also help analyze mutants or situations in which not all meiocytes behave similarly: to distinguish between populations of meiocytes whose progression is arrested, or with a population of meiocytes that progress at various rates through meiosis and will eventually exit meiosis after a prolonged time, as exemplified by tam and the weak loss-of-function allele smg7-1 of SUPPRESSOR WITH MORPHOGENETIC EFFECTS ON GENITALIA7, which encodes a factor involved in RNA decay. In the case of tam mutants, defective in a CDKA;1 cyclin cofactor, meiocytes show prolonged late-pachytene/diplotene stages, lasting 3-5 h longer than in the wild type. Notably, different populations of meiocytes were identified with distinct microtubules structures (Prusicki et al., 2019). Live-cell imaging of smg7-1 revealed that the previously described arrest at anaphase II occasionally results from a regression of cells that already entered telophase II. Such a regression was not observed in fixed material, where it would likely have been misinterpreted as slower progression of a sub-population of meiocytes (Valuchova et al., 2020). These examples underscore the power of live-cell imaging.

\section{Microtubule Rearrangements and Regulation}

The cytoskeleton undergoes major rearrangements during meiosis, as illustrated in Arabidopsis. Microtubules are evenly distributed across the cytoplasm at the onset of meiosis but take on an arc-like structure resembling a half-moon during early prophase. Similar to mitosis, a full-moon-like microtubule structure surrounds the nucleus later in prophase; when the nuclear envelope breaks down, microtubules rapidly rearrange to form the first spindle in metaphase I and the second spindle in metaphase II (Prusicki et al., 2019). These different arrangements offer visible native markers for the identification of meiotic stages in the absence of a specific meiotic marker and in an imaging setup that does not reach the same level of chromosomal resolution achieved by cell spreads (Prusicki et al., 2019).

Altered microtubule dynamics can have a strong effect on the meiotic outcome, as seen in the maize mutant $d v 1$ (divergent spindle1), which carries a mutation in ZmKin6, a member of the kinesin-14A subfamily of minus end-directed microtubule motor proteins. The $d v 1$ mutant shows an aberrant spindle shape at metaphase I, ultimately resulting in lagging chromosomes at anaphase I. This phenotype was validated by movies of metaphase I of isolated maize meiocytes (Higgins et al., 2016).

Moreover, microtubules are affected in mutants with lower CDK activity, for example, in tam, in which phragmoplast-like structures are observed prior to nuclear envelope breakdown (Prusicki et al., 2019). Similarly, ectopic phragmoplasts were observed when a weak loss-of-function allele of $c d k a ; 1$ was combined with mutants of $C D K D ; 3$, a CDK-ACTIVATING KINASE (cdka; $\left.1^{V F} c d k d ; 3\right)$. Moreover, meiocytes of $c d k a ; 1^{V F}$ $c d k d ; 3$ plants also displayed loss of the half-moon and full-moon structures and premature cytokinesis after the first male meiotic division (Sofroni et al., 2020).

\section{Chromosome Movements and Segregation}

Chromosome trajectories during prophase in maize were described by Sheehan and Pawlowski (2009) as following three types of movement: rotational movement of the entire chromatin, rapid short-distance oscillations of extruded chromosome segments, and slower paced movements of chromosome segments located inside the chromatin mass. Moreover, these movements vary considerably between different meiotic phases; zygotene chromosomes move rapidly in a short-range pattern, while chromosome arms move more slowly and cover longer distances in pachytene. Chromosome movements disappear when the anthers are treated with drugs that affect cytoskeleton polymerization (latrunculin B and colchicine), demonstrating that they depend on both actin and tubulin.

The shape of the nuclear envelope (NE) also changes during prophase, not as a consequence of chromosome movements, but due to the force of chromosome movements itself (Sheehan and Pawlowski, 2009). Chromosomes move rapidly in Arabidopsis. In addition, the nucleus and the nucleolus show a characteristic movement pattern during Arabidopsis prophase, with the nucleus moving from a central position during premeiotic stages to a lateral position during early prophase, only to then return to a central position at late pachytene-diplotene. Similarly, the nucleolus is located at the periphery of the nucleus at the onset of leptotene and stays there until diakinesis. Moreover, both the nucleus (chromatin mass) and the nucleolus appear to spin at different speeds during the entire prophase I (Prusicki et al., 2019). The dynamics of prophase chromosomes have been linked to homologous chromosome pairing (Sheehan and Pawlowski, 2009). However, the functional relevance of chromosome movements is not yet fully understood, although it is hoped that live-cell imaging will help reveal their role and regulation.

At later stages of meiosis, chromosomes are highly condensed and are distributed to opposite cell poles during anaphase I and II. These movements are mediated by spindle microtubules attached to kinetochores, multi-protein structures that connect chromosomes to the microtubule fibers of the spindle. The speed of chromosome segregation was accurately measured in maize meiocytes by Yu et al. (1997). Maize chromosomal architecture is characterized by the presence of knobs, also called neocentromeres, which offer a second anchoring point between chromatin and the cytoskeleton besides centromeres or kinetochores. Knobs and kinetochores promoted movements with different kinetics, with speeds of 1.08 and $0.78 \mathrm{~mm} / \mathrm{min}$, respectively. However, the faster movements of knobs did not appear to influence the speed of the kinetochore of the same chromosome, ultimately causing a stretching of chromosome arms during anaphase, but not an overall faster chromosome movement, demonstrating that the predominant force during meiotic anaphase was dependent on kinetochore movements (Yu et al., 1997). Furthermore, live-cell imaging revealed that the two pools of homologous chromosomes segregate toward the cell poles following an asymmetric motion: The chromosome mass that is furthest from the edge of the cell moves faster and farther to reestablish the lost symmetry 
necessary to achieve a balanced cytokinesis. The phragmoplast forms at the half-point between the chromosome masses and not at the spindle zone, as previously hypothesized (Nannas et al., 2016).

\section{Protein Turnover and Regulation of Meiosis}

Live-cell imaging is also a powerful tool to monitor protein abundance and, thus, the regulation of meiotic progression. Examples include the above-mentioned quantitative dissection of CDKA;1 localization (Yang et al., 2020).

Live-cell imaging offered a clear and quantitative picture of the gradual loss of REC8 from chromosomes mediated by WAPL, which provided evidence for the prophase pathway of cohesion removal during meiosis (Yang et al., 2019). Likewise, the molecular mechanisms underpinning the protection of centromeric cohesion at anaphase I were assessed by the imaging of plants expressing REC8pro:REC8-GFP. The plant homolog of securin, PANS1, prevents the cleavage of centromeric cohesin by the separase protease. REC 8 removal at chromosome arms requires the degradation of PANS1 to release the repression imposed on separase, ultimately promoting the segregation of the chromosome homologs. The direct microscopy observations of REC8-GFP behavior in meiocytes expressing a variant of PANS1 that can no longer be degraded (DMC1pro:PANS1 $\triangle D$ ) demonstrated that PANS1 degradation is necessary to remove the remaining REC8 from chromosome arms at anaphase I and to promote homolog segregation (Cromer et al., 2019).

\section{MEIOTIC RECOMBINATION OBSERVATIONS BY LIVE-CELL IMAGING}

Recombination is a key event during meiosis; therefore, understanding its underlying mechanisms and regulatory principles is important in many fundamental and applied aspects of plant life: to obtain insights into genome evolution, biodiversity, and breeding (Grelon, 2016; Lambing et al., 2017; Wang and Copenhaver, 2018).

Several techniques have been adopted to investigate recombination, ranging from immunolocalization on cell spreads and in situ hybridization (among many: Schwarzacher, 2003; Kurzbauer et al., 2018; Martinez-Garcia et al., 2018; Sims et al., 2019) to three-dimensional immunolocalization (Hurel et al., 2018), fluorescent transgenic lines (FTLs) to visualize segregation (Francis et al., 2007), and genotyping by sequencing or chromatin immunoprecipitation followed by sequencing (ChIP-seq) methods to explore the role of epigenetic modifications on recombination cold and hot spots (Pawlowski et al., 2013; Lambing and Heckmann, 2018; Pradillo and Heckmann, 2020).

Being able to follow recombination in real time will open the door to a new level of understanding of this central aspect of meiosis. A first example comes from live-cell imaging of meiosis in Arabidopsis under heat stress $\left(34^{\circ} \mathrm{C}\right)$ that uncovered the presence of a long-doubted recombination checkpoint, also known as pachytene checkpoint (De Jaeger-Braet et al., 2021).
In animals and yeast, aberrant recombination structures and the complete loss of recombination cause a delay of pachytene (Bishop et al., 1992; Rockmill et al., 1995; Barchi et al., 2005). This arrest is controlled by the checkpoint kinase ATAXIA TELANGIECTASIA MUTATED (ATM). Since in Arabidopsis and other plants the loss of recombination, as for instance seen in $d m c 1$ mutants, does not cause meiotic arrest, it was concluded that plants do not possess a pachytene checkpoint (Couteau et al., 1999; Grelon et al., 2001; Caryl et al., 2003; Higgins et al., 2004; Li et al., 2004, 2009; Jones and Franklin, 2008; Wijnker and Schnittger, 2013). However, imaging $d m c 1$ and other mutants in which recombination is abolished such as spol1-1 at $34^{\circ} \mathrm{C}$ revealed that the duration of pachytene reverted to almost the level seen in the wildtype at $21^{\circ} \mathrm{C}$ indicating that the pachytene delay is recombination dependent. Importantly, the pachytene delay in Arabidopsis is also absent in atm mutants exposed to $34^{\circ} \mathrm{C}$ (De Jaeger-Braet et al., 2021). Thus, it appears that there is a pachytene checkpoint in plants. However, this checkpoint likely monitors aberrant recombination structures rather than the absence of COs.

Now, it will be very interesting to further zoom into these defective recombination structures knowing that heat stress and other environmental conditions can modify the position and number of COs (Phillips et al., 2015; Morgan et al., 2017; De Storme and Geelen, 2020). To this end, it will be very informative to follow the recombination machinery itself. However, live-cell imaging of recombination is challenging and is largely limited by three important factors: the current achievable resolution, the movement of chromosomes, and the availability of reporter lines to label proteins of the recombination machinery and to highlight specific chromosomal regions such as the $45 \mathrm{~S}$ rDNA region and telomeres in vivo.

As outlined above, the dynamics of the meiotic chromosome axis, which is key for recombination, is well established by following components such as ASY1, ASY3, and REC8. New reporter lines and live-cell imaging assays now need to be established for the analysis of DSB formation, strand invasion, and CO resolution. These new tools will make it possible to study the appearance and disappearance of each component of the recombination machinery to determine their relative order and how the recombination machinery is affected in various mutant backgrounds.

These studies may explain how a defined DSB site is resolved as a CO, how a CO is assigned to class I or class II, or how $\mathrm{CO}$ interference is established, which is far from being fully understood. As recently shown by immuno-cytochemistry, the E3 ligase HEI10, which is a crucial determinant of type I COs and $\mathrm{CO}$ interference, is present along the chromosome axis in early pachytene. It then accumulates in growing foci, which are evenly distributed at the expense of smaller, closely spaced peaks in mid and late pachytene (Morgan et al., 2021). It will be now very interesting to follow these foci in real time and correlate their dynamics with other type I CO components by live-cell imaging.

This work may also be extendable to studying recombination during female meiosis, which is differently regulated in both Arabidopsis and crop species (Giraut et al., 2011; Qin et al., 2014; Zhao et al., 2014; Kianian et al., 2018). Furthermore, 
live-cell imaging has also the great potential to contribute to an understanding of species-specific difference in meiosis. For instance, the duration of leptotene and early pachytene was extended in spo11-1 mutants in Arabidopsis while in yeast, the corresponding mutants progress faster through meiosis than the wildtype (Klapholz et al., 1985; Jiao et al., 1999; Cha et al., 2000; De Jaeger-Braet et al., 2021). Thus, the era of live-cell imaging for meiosis has just begun, with many exciting discoveries ahead of us.

\section{AUTHOR CONTRIBUTIONS}

MP, MB, KS, YH, and AS selected the content and the references, contributed to define the content structure and revised and approved the article. MP, MB and KS designed the figures and the

\section{REFERENCES}

Armstrong, S. J., Franklin, F. C. H., and Jones, G. H. (2003). A meiotic time-course for Arabidopsis thaliana. Sex Plant Reprod. 16, 141-149. doi: 10.1007/s00497003-0186-4

Balboni, M., Yang, C., Komaki, S., Brun, J., and Schnittger, A. (2020). COMET functions as a $\mathrm{PCH} 2$ cofactor in regulating the HORMA domain protein ASY1. Curr. Biol. 30, 4113-4127.e6. doi: 10.1016/j.cub.202 0.07.089

Barber, H. N. (1942). The experimental control of chromosome pairing in Fritillaria. J. Genet. 43, 359-374. doi: 10.1007/BF0298 2908

Barchi, M., Mahadevaiah, S., Di Giacomo, M., Baudat, F., de Rooij, D. G., Burgoyne, P. S., et al. (2005). Surveillance of different recombination defects in mouse spermatocytes yields distinct responses despite elimination at an identical developmental stage. Mol. Cell. Biol. 25, 7203-7215. doi: 10.1128/MCB.25.16. 7203-7215.2005

Bastiaens, P. I., and Pepperkok, R. (2000). Observing proteins in their natural habitat: the living cell. Trends Biochem. Sci. 25, 631-637. doi: 10.1016/s09680004(00)01714-x

Bennett, M. D. (1971). The duration of meiosis. Proc. R. Soc. Lond. B 178, 277-299. doi: $10.1098 / \mathrm{rspb} .1971 .0066$

Bennett, M. D. (1977). The time and duration of meiosis. Philos. Trans. R. Soc. Lond. B 277, 201-226. doi: 10.1098/rstb.1977.0012

Bennett, M. D., and Finch, R. A. (1971). Duration of meiosis in barley. Genet. Res. 17, 209-214. doi: 10.1017/S0016672300012234

Bennett, M. D., and Kaltsikes, P. J. (1973). The duration of meiosis in a diploid rye, a tetraploid wheat and the hexaploid triticale derived from them. Can. J. Genet. Cytol. 15, 671-679. doi: 10.1139/g73-080

Bennett, M. D., and Smith, J. B. (1972). The effects of polyploidy on meiotic duration and pollen development in cereal anthers. Proc. R. Soc. Lond. B 181, 81-107.

Bennett, M. D., Chapman, V., and Riley, R. (1971). The duration of meiosis in pollen mother cells of wheat, rye and Triticale. Proc. R. Soc. Lond. Ser. B. Biol. Sci. 178, 259-275. doi: 10.1098/rspb.1971.0065

Bennett, M. D., Dover, G. A., and Riley, R. (1974). Meiotic duration in wheat genotypes with or without homoeologous meiotic chromosome pairing. Proc. R. Soc. Lond. Ser. B. Biol. Sci. 187, 191-207. doi: 10.1098/rspb.1974. 0069

Bennett, M. D., Smith, J. B., and Kemble, R. (1972). The effect of temperature on meiosis and pollen development in wheat and rye. Can. J. Genet. Cytol. 14, 615-624. doi: 10.1139/g72-076

Bennett, M. D., Stern, H., and Riley, R. (1975). The time and duration of female meiosis in Lilium. Proc. R. Soc. Lond. Ser. B. Biol. Sci. 188, 459-475. doi: 10.1098/rspb.1975.0031

Biedermann, S., Harashima, H., Chen, P., Heese, M., Bouyer, D., Sofroni, K., et al. (2017). The retinoblastoma homolog RBR1 mediates localization of the tables. MP, MB and AS wrote the article. All authors contributed to the article and approved the submitted version.

\section{FUNDING}

This work was supported by a grant from the Human Frontier Science Program (RGP0023) and a grant from the BMBF to AS (MeioCheck).

\section{ACKNOWLEDGMENTS}

We are grateful to Joke de Jaeger-Braet (University of Hamburg) and Konstantinos Lampou (University of Hamburg) for helpful discussion of the manuscript. We thank the Plant Editors for editing this manuscript.

repair protein RAD51 to DNA lesions in Arabidopsis. EMBO J. 36, 1279-1297. doi: 10.15252/embj.201694571

Bishop, D. K., Park, D., Xu, L., and Kleckner, N. (1992). DMC1: a meiosis-specific yeast homolog of $\mathrm{E}$. coli recA required for recombination, synaptonemal complex formation, and cell cycle progression. Cell 69, 439-456. doi: 10.1016/ 0092-8674(92)90446-J

Bomblies, K., Higgins, J. D., and Yant, L. (2015). Meiosis evolves: adaptation to external and internal environments. New Phytol. 208, 306-323. doi: 10.1111/ nph.13499

Brownfield, L., Yi, J., Jiang, H., Minina, E. A., Twell, D., and Köhler, C. (2015). Organelles maintain spindle position in plant meiosis. Nat. Commun. 6:6492. doi: $10.1038 /$ ncomms7492

Buchanan, B. B., Gruissem, W., and Jones, R. L. (2015). Biochemistry and Molecular Biology of Plants. Hoboken, NJ: John Wiley \& Sons.

Bulankova, P., Riehs-Kearnan, N., Nowack, M. K., Schnittger, A., and Riha, K. (2010). Meiotic progression in Arabidopsis is governed by complex regulatory interactions between SMG7, TDM1, and the meiosis I-specific cyclin TAM. Plant Cell 22, 3791-3803. doi: 10.1105/tpc.110.078378

Cahoon, C. K., Yu, Z., Wang, Y., Guo, F., Unruh, J. R., Slaughter, B. D., et al. (2017). Superresolution expansion microscopy reveals the three-dimensional organization of the Drosophila synaptonemal complex. Proc. Natl. Acad. Sci. U.S.A. 114, E6857-E6866. doi: 10.1073/pnas.1705623114

Caryl, A. P., Jones, G. H., and Franklin, F. C. (2003). Dissecting plant meiosis using Arabidopsis thaliana mutants. J. Exp. Bot. 54, 25-38. doi: 10.1093/jxb/erg041

Cha, R. S., Weiner, B. M., Keeney, S., Dekker, J., and Kleckner, N. (2000). Progression of meiotic DNA replication is modulated by interchromosomal interaction proteins, negatively by Spo11p and positively by Rec8p. Genes Dev. 14, 493-503. doi: 10.1101/gad.14.4.493

Chambon, A., West, A., Vezon, D., Horlow, C., Muyt, A. D., Chelysheva, L., et al. (2018). Identification of ASYNAPTIC4, a component of the meiotic chromosome axis. Plant Physiol. 178, 233-246. doi: 10.1104/pp.17.01725

Chamberlain, C. J. (1935). Gymnosperms, Structure and Evolution. Chicago: Chicago University Press, 286-287.

Chan, A., and Zacheus Cande, W. (2000). Maize meiocytes in culture. Plant Cell Tissue Organ Cult. 60:187. doi: 10.1023/A:1006420425525

Chelysheva, L., Vezon, D., Chambon, A., Gendrot, G., Pereira, L., Lemhemdi, A., et al. (2012). The Arabidopsis HEI10 is a new ZMM protein related to Zip3. PLoS Genet. 8:e1002799. doi: 10.1371/journal.pgen.1002799

Chen, Z., Higgins, J. D., Hui, J. T. L., Li, J., Franklin, F. C. H., and Berger, F. (2011). Retinoblastoma protein is essential for early meiotic events in Arabidopsis. EMBO J. 30, 744-755. doi: 10.1038/emboj.2010.344

Chikashige, Y., Ding, D. Q., Funabiki, H., Haraguchi, T., Mashiko, S., Yanagida, M., et al. (1994). Telomere-led premeiotic chromosome movement in fission yeast. Science 264, 270-273. doi: 10.1126/science.8146661

Christophorou, N., Rubin, T., Bonnet, I., Piolot, T., Arnaud, M., and Huynh, J.R. (2015). Microtubule-driven nuclear rotations promote meiotic chromosome dynamics. Nat. Cell Biol. 17, 1388-1400. doi: 10.1038/ncb3249 
Church, K., and Wimber, D. E. (1969). Meiosis in the grasshopper: chiasma frequency after elevated temperature and x-rays. Can. J. Genet. Cytol. 11, 209-216. doi: 10.1139/g69-025

Colombié, N., Głuszek, A. A., Meireles, A. M., and Ohkura, H. (2013). MeiosisSpecific stable binding of augmin to acentrosomal spindle poles promotes biased microtubule assembly in oocytes. PLoS Genet. 9:e1003562. doi: 10.1371/ journal.pgen.1003562

Conrad, M. N., Lee, C.-Y., Chao, G., Shinohara, M., Kosaka, H., Shinohara, A., et al. (2008). Rapid telomere movement in meiotic prophase is promoted by NDJ1, MPS3, and CSM4 and is modulated by recombination. Cell 133, 1175-1187. doi: 10.1016/j.cell.2008.04.047

Couteau, F., Belzile, F., Horlow, C., Grandjean, O., Vezon, D., and Doutriaux, M. P. (1999). Random chromosome segregation without meiotic ar-rest in both male and female meiocytes of a dmcl mutant of Arabidopsis. Plant Cell 11, 1623-1634. doi: 10.1105/tpc.11.9.1623

Cromer, L., Jolivet, S., Singh, D. K., Berthier, F., Winne, N. D., Jaeger, G. D., et al. (2019). Patronus is the elusive plant securin, preventing chromosome separation by antagonizing separase. Proc. Natl. Acad. Sci. U.S.A. 116, 1601816027. doi: 10.1073/pnas.1906237116

Da Ines, O., Degroote, F., Goubely, C., Amiard, S., Gallego, M. E., and White, C. I. (2013). Meiotic recombination in Arabidopsis is catalysed by DMC1, with RAD51 playing a supporting role. PLoS Genet. 9:e1003787. doi: 10.1371/journal. pgen. 1003787

Dangol, S., Singh, R., Chen, Y., and Jwa, N.-S. (2017). Visualization of multicolored in vivo organelle markers for co-localization studies in Oryza sativa. Mol. Cells 40, 828-836. doi: 10.14348/molcells.2017.0045

De Jaeger-Braet, J., Krause, L., Buchholz, A., and Schnittger, A. (2021). Heat stress reveals a specialized variant of the pachytene checkpoint in meiosis of Arabidopsis thaliana. Plant Cell koab257. doi: 10.1093/plcell/koab257

De La Peña, A. (1986). 'In vitro' culture of isolated meiocytes of rye, Secale cereale L. Environ. Exp. Bot. 26, 17-23. doi: 10.1016/0098-8472(86)90048-1

De Storme, N., and Geelen, D. (2020). High temperatures alter cross-over distribution and induce male meiotic restitution in Arabidopsis thaliana. Commun. Biol. 3, 1-15. doi: 10.1038/s42003-020-0897-1

De Storme, N., Keçeli, B. N., Zamariola, L., Angenon, G., and Geelen, D. (2016). CENH3-GFP: a visual marker for gametophytic and somatic ploidy determination in Arabidopsis thaliana. BMC Plant Biol. 16:1. doi: 10.1186/ s12870-015-0700-5

DeBlasio, S. L., Sylvester, A. W., and Jackson, D. (2010). Illuminating plant biology: using fluorescent proteins for high-throughput analysis of protein localization and function in plants. Brief. Funct. Genomics 9, 129-138. doi: 10.1093/bfgp/ elp060

Dreissig, S., Schiml, S., Schindele, P., Weiss, O., Rutten, T., Schubert, V., et al. (2017). Live-cell CRISPR imaging in plants reveals dynamic telomere movements. Plant J. 91, 565-573. doi: 10.1111/tpj.13601

Echevarría, C., Gutierrez, C., and Desvoyes, B. (2021). Tools for assessing cell cycle progression in plants. Plant Cell Physiol. 62, 1231-1238. doi: 10.1093/pcp/ pcab066

Ekberg, I., and Eriksson, G. (1965). Demonstration of meiosis and pollen mitosis by photomicrograps and the distribution of meiotic stages in barley spikes. Hereditas 53, 127-136. doi: 10.1111/j.1601-5223.1965.tb01985.x

Enguita-Marruedo, A., Cappellen, W. A. V., Hoogerbrugge, J. W., Carofiglio, F., Wassenaar, E., Slotman, J. A., et al. (2018). Live cell analyses of synaptonemal complex dynamics and chromosome movements in cultured mouse testis tubules and embryonic ovaries. Chromosoma 127, 341-359. doi: 10.1007/ s00412-018-0668-7

Era, A., Tominaga, M., Ebine, K., Awai, C., Saito, C., Ishizaki, K., et al. (2009). Application of lifeact reveals F-actin dynamics in Arabidopsis thaliana and the liverwort, marchantia polymorpha. Plant Cell Physiol. 50, 1041-1048. doi: $10.1093 / \mathrm{pcp} / \mathrm{pcp} 055$

Erickson, R. O. (1948). Cytological and growth correlations in the flower bud and anther of Lilium longiflorum. Am. J. Bot. 35, 729-739. doi: 10.1002/j.1537-2197. 1948.tb08143.x

Feijó, J. A., and Cox, G. (2001). Visualization of meiotic events in intact living anthers by means of two-photon microscopy. Micron 32, 679-684. doi: 10.1016/ S0968-4328(00)00097-4

Finch, R. A., and Bennett, M. D. (1972). The duration of meiosis in diploid and autotetraploid barley. Can. J. Genet. Cytol. 14, 507-515. doi: 10.1139/g72-063
Francis, K. E., Lam, S. Y., Harrison, B. D., Bey, A. L., Berchowitz, L. E., and Copenhaver, G. P. (2007). Pollen tetrad-based visual assay for meiotic recombination in Arabidopsis. Proc. Natl. Acad. Sci. U.S.A. 104, 3913-3918. doi: 10.1073/pnas.0608936104

Giraut, L., Falque, M., Drouaud, J., Pereira, L., Martin, O. C., and Mézard, C. (2011). Genome-Wide crossover distribution in Arabidopsis thaliana meiosis reveals sex-specific patterns along chromosomes. PLoS Genet. 7:e1002354. doi: 10.1371/journal.pgen.1002354

Golubovskaya, I. N., Harper, L. C., Pawlowski, W. P., Schichnes, D., and Cande, W. Z. (2002). The pam 1 gene is required for meiotic bouquet formation and efficient homologous synapsis in maize (Zea mays L.). Genetics 162, 1979-1993. doi: $10.1093 /$ genetics/162.4.1979

Grelon, M. (2016). Meiotic recombination mechanisms. C. R. Biol. 339, 247-251. doi: 10.1016/j.crvi.2016.04.003

Grelon, M., Vezon, D., Gendrot, G., and Pelletier, G. (2001). AtSPO11-1 is necessary for efficient meiotic recombination in plants. EMBO J. 20, 589-600. doi: $10.1093 /$ emboj/20.3.589

Hafidh, S., and Honys, D. (2021). Reproduction multitasking: the male gametophyte. Annu. Rev. Plant Biol. 72, 581-614. doi: 10.1146/annurevarplant-080620-021907

Hamamura, Y., Saito, C., Awai, C., Kurihara, D., Miyawaki, A., Nakagawa, T., et al. (2011). Live-Cell imaging reveals the dynamics of two sperm cells during double fertilization in Arabidopsis thaliana. Curr. Biol. 21, 497-502. doi: 10.1016/j.cub. 2011.02.013

Harashima, H., Dissmeyer, N., and Schnittger, A. (2013). Cell cycle control across the eukaryotic kingdom. Trends Cell Biol. 23, 345-356. doi: 10.1016/j.tcb.2013. 03.002

Harashima, H., Dissmeyer, N., Hammann, P., Nomura, Y., Kramer, K., Nakagami, H., et al. (2016). Modulation of plant growth in vivo and identification of kinase substrates using an analog-sensitive variant of CYCLIN-DEPENDENT KINASE A;1. BMC Plant Biol. 16:209. doi: 10.1186/s12870-016-0900-7

Hater, F., Nakel, T., and Groß-Hardt, R. (2020). Reproductive multitasking: the female gametophyte. Annu. Rev. Plant Biol. 71, 517-546. doi: 10.1146/annurevarplant-081519-035943

Hernandez, M. R., Davis, M. B., Jiang, J., Brouhard, E. A., Severson, A. F., and Csankovszki, G. (2018). Condensin I protects meiotic cohesin from WAPL1 mediated removal. PLoS Genetics 14:e1007382. doi: 10.1371/journal.pgen. 1007382

Hertwig, W. A. O. (1876). Beiträge zur kenntniss der bildung, befruchtung und theilung des thierischen eies. Morphol. Jahrbuch 1, 347-434.

Heslop-Harrison, J. (1966). Cytoplasmic connexions between angiosperm meiocytes. Ann. Bot. 30, 221-222. doi: 10.1093/oxfordjournals.aob.a084069

Higashiyama, T., Yabe, S., Sasaki, N., Nishimura, Y., Miyagishima, S., Kuroiwa, H., et al. (2001). Pollen tube attraction by the synergid cell. Science 293, 1480-1483. doi: 10.1126/science. 1062429

Higgins, D. M., Nannas, N. J., and Dawe, R. K. (2016). The maize divergent spindle1 (dv1) gene encodes a Kinesin-14A motor protein required for meiotic spindle pole organization. Front. Plant Sci. 7:1277. doi: 10.3389/fpls.2016.01277

Higgins, J. D., Armstrong, S. J., Franklin, F. C. H., and Jones, G. H. (2004). The Arabidopsis MutS homolog AtMSH4 functions at an early step in recombination: evidence for two classes of recombination in Arabidopsis. Genes Dev. 18, 2557-2570. doi: 10.1101/gad.317504

Higgins, J. D., Perry, R. M., Barakate, A., Ramsay, L., Waugh, R., Halpin, C., et al. (2012). Spatiotemporal asymmetry of the meiotic program underlies the predominantly distal distribution of meiotic crossovers in barley. Plant Cell 24, 4096-4109. doi: 10.1105/tpc.112.102483

Holubcová, Z., Howard, G., and Schuh, M. (2013). Vesicles modulate an actin network for asymmetric spindle positioning. Nat. Cell Biol. 15:937. doi: 10.1038/ ncb2802

Hotta, Y., and Stern, H. (1963). Synthesis of messenger-like ribonucleic acid and protein during meiosis in isolated cells of trillium erectum. J. Cell Biol. 19, 45-58. doi: 10.1083/jcb.19.1.45

Hsu, S.-Y., Huang, Y.-C., and Peerson, P. A. (1988). Development pattern of microspores in Zea mays L. the maturation of upper and lower florets of spikelets among an assortment of genotypes. Madyca 33, 77-98.

Hughes, S. E., Beeler, J. S., Seat, A., Slaughter, B. D., Unruh, J. R., Bauerly, E., et al. (2011). Gamma-Tubulin is required for bipolar spindle assembly and for proper kinetochore microtubule attachments during prometaphase I 
in Drosophila oocytes. PLoS Genet. 7:e1002209. doi: 10.1371/journal.pgen.100 2209

Hurel, A., Phillips, D., Vrielynck, N., Mézard, C., Grelon, M., and Christophorou, N. (2018). A cytological approach to studying meiotic recombination and chromosome dynamics in Arabidopsis thaliana male meiocytes in three dimensions. Plant J. 95, 385-396. doi: 10.1111/tpj.13942

Ingouff, M., Selles, B., Michaud, C., Vu, T. M., Berger, F., Schorn, A. J., et al. (2017). Live-cell analysis of DNA methylation during sexual reproduction in Arabidopsis reveals context and sex-specific dynamics controlled by noncanonical RdDM. Genes Dev. 31, 72-83. doi: 10.1101/gad.2893 97.116

Ito, M., and Stern, H. (1967). Studies of meiosis in vitro: I. In vitro culture of meiotic cells. Dev. Biol. 16, 36-53. doi: 10.1016/0012-1606(67)90016-4

Ito, Y., Uemura, T., and Nakano, A. (2018). The Golgi entry core compartment functions as a COPII-independent scaffold for ER-to-Golgi transport in plant cells. J. Cell Sci. 131:jcs203893. doi: 10.1242/jcs.203893

Izhar, S., and Frankel, R. (1973). Duration of meiosis in Petunia anthers in vivo and in floral bud culture. Acta Bot. Neerl. 22, 14-22.

Jackson, N., Sanchez-Moran, E., Buckling, E., Armstrong, S. J., Jones, G. H., and Franklin, F. C. H. (2006). Reduced meiotic crossovers and delayed prophase I progression in AtMLH3-deficient Arabidopsis. EMBO J. 25, 1315-1323. doi: 10.1038/sj.emboj.7600992

Jiao, K., Bullard, S. A., Salem, L., and Malone, R. E. (1999). Coordination of the initiation of recombination and the reductional division in meiosis in Saccharomyces cerevisiae. Genetics 152, 117-128. doi: 10.1093/genetics/152.1. 117

Jin, W., Lamb, J. C., Zhang, W., Kolano, B., Birchler, J. A., and Jiang, J. (2008). Histone modifications associated with both $\mathrm{A}$ and $\mathrm{B}$ chromosomes of maize. Chromosome Res. 16, 1203-1214. doi: 10.1007/s10577-008-1269-8

Jones, A. M., Danielson, J. Å, ManojKumar, S. N., Lanquar, V., Grossmann, G., and Frommer, W. B. (2014). Abscisic acid dynamics in roots detected with genetically encoded FRET sensors. eLife 3:e01741. doi: 10.7554/eLife.01741

Jones, G. H., and Franklin, F. C. (2008). "Meiosis in Arabidopsis thaliana: recombination, chromosome organization and meiotic progression," in Recombination and Meiosis: Crossing-Over and Disjunction, eds R. Egel and D. H. Lankenau (Berlin: Springer), 279-306. doi: 10.1023/a:1022831724990

Keeney, S. ed. (2009). Meiosis: Cytological Methods, Vol. 2. Totowa, NJ: Humana Press. doi: 10.1007/978-1-60761-103-5

Kemp, C. L. (1964). The effects of inhibitors of RNA and protein synthesis on cytological development during meiosis. Chromosoma 15, 652-665. doi: 10. 1007/BF00319997

Khosravi, S., Schidele, P., Gladilin, E., Dunemann, F., Rutten, T., Putcha, H., et al. (2020). Application of aptamers improves CRISPR-based live imaging of plant telomeres. Front. Plant Sci. 11:1254. doi: 10.3389/fpls.2020.01254

Kianian, P. M. A., Wang, M., Simons, K., Ghavami, F., He, Y., Dukowic-Schulze, S., et al. (2018). High-resolution crossover mapping reveals similarities and differences of male and female recombination in maize. Nat. Commun. 9:2370. doi: 10.1038/s41467-018-04562-5

Kimata, Y., Higaki, T., Kawashima, T., Kurihara, D., Sato, Y., Yamada, T., et al. (2016). Cytoskeleton dynamics control the first asymmetric cell division in Arabidopsis zygote. Proc. Natl. Acad. Sci. U.S.A. 113, 14157-14162. doi: 10. 1073/pnas. 1613979113

Kitajima, T. S., Ohsugi, M., and Ellenberg, J. (2011). Complete kinetochore tracking reveals error-prone homologous chromosome biorientation in mammalian oocytes. Cell 146, 568-581. doi: 10.1016/j.cell.2011.07.031

Klapholz, S., Waddell, C. S., and Esposito, R. E. (1985). The role of the SPO11 gene in meiotic recombination in yeast. Genetics 110, 187-216. doi: 10.1093/genetics/ 110.2.187

Komaki, S., and Schnittger, A. (2017). The spindle assembly checkpoint in Arabidopsis is rapidly shut off during severe stress. Dev. Cell 43, 172-185.e5. doi: 10.1016/j.devcel.2017.09.017

Komaki, S., Takeuchi, H., Hamamura, Y., Heese, M., Hashimoto, T., and Schnittger, A. (2020). Functional analysis of the plant chromosomal passenger complex. Plant Physiol. 183, 1586-1599. doi: 10.1104/pp.20. 00344

Koszul, R., and Kleckner, N. (2009). Dynamic chromosome movements during meiosis: a way to eliminate unwanted connections? Trends Cell Biol. 19, 716724. doi: 10.1016/j.tcb.2009.09.007
Kurzbauer, M.-T., Pradillo, M., Kerzendorfer, C., Sims, J., Ladurner, R., Oliver, C., et al. (2018). Arabidopsis thaliana FANCD2 promotes meiotic crossover formation. Plant Cell 30, 415-428. doi: 10.1105/tpc.17.00745

Kyogoku, H., and Kitajima, T. S. (2017). Large cytoplasm is linked to the errorprone nature of oocytes. Dev. Cell 41, 287-298.e4. doi: 10.1016/j.devcel.2017. 04.009

Lambing, C., and Heckmann, S. (2018). Tackling plant meiosis: from model research to crop improvement., tackling plant meiosis: from model research to crop improvement. Front. Plant Sci. 9:829. doi: 10.3389/fpls.2018.00829

Lambing, C., Franklin, F. C. H., and Wang, C.-J. R. (2017). Understanding and manipulating meiotic recombination in plants[OPEN]. Plant Physiol. 173, 1530-1542. doi: 10.1104/pp.16.01530

Lee, C.-Y., Bisig, C. G., Conrad, M. N., Ditamo, Y., Previato de Almeida, L., Dresser, M. E., et al. (2020). Telomere-led meiotic chromosome movements: recent update in structure and function. Nucleus 11, 111-116. doi: 10.1080/19491034. 2020.1769456

Lee, C.-Y., Conrad, M. N., and Dresser, M. E. (2012). Meiotic chromosome pairing is promoted by telomere-led chromosome movements independent of bouquet formation. PLoS Genet. 9:e1002730. doi: 10.1371/journal.pgen.00 2730

Lee, C.-Y., Horn, H. F., Stewart, C. L., Burke, B., Bolcun-Filas, E., Schimenti, J. C., et al. (2015). Mechanism and regulation of rapid telomere prophase movements in mouse meiotic chromosomes. Cell Rep. 11, 551-563. doi: 10.1016/j.celrep. 2015.03.045

Li, W., Chen, C., Markmann-Mulisch, U., Timofejeva, L., Schmelzer, E., Ma, H., et al. (2004). The Arabidopsis AtRAD51 gene is dispensable for vegetative development but required for meiosis. Proc. Natl. Acad. Sci. U.S.A. 101, 1059610601. doi: 10.1073/pnas.0404110101

Li, X. C., Barringer, B. C., and Barbash, D. A. (2009). The pachytene check- point and its relationship to evolutionary patterns of polyploidiza-tion and hybrid sterility. Heredity 102, 24-30. doi: 10.1038/hdy.2008.84

Liao, C.-Y., and Weijers, D. (2018). A toolkit for studying cellular reorganization during early embryogenesis in Arabidopsis thaliana. Plant J. 93, 963-976. doi: $10.1111 /$ tpj.13841

Lindgren, D., Eriksson, G., and Ekberg, I. (1969). The relative duration of the meiotic stages in pollen mother cells of barley. Hereditas 63, 205-212. doi: 10.1111/j.1601-5223.1969.tb02262.x

Liu, B., Storme, N. D., and Geelen, D. (2017). Gibberellin induces diploid pollen formation by interfering with meiotic cytokinesis. Plant Physiol. 173, 338-353. doi: 10.1104/pp.16.00480

Magnard, J.-L., Yang, M., Chen, Y.-C. S., Leary, M., and McCormick, S. (2001). The Arabidopsis gene tardy asynchronous meiosis is required for the normal pace and synchrony of cell division during male meiosis. Plant Physiol. 127, 1157-1166. doi: 10.1104/pp.010473

Marquardt, H. (1937). Die meiosis von oenothera I. Z. Zellforsch. 27, 159-210. doi: $10.1007 / \mathrm{BF} 01880081$

Martinez-Garcia, M., Schubert, V., Osman, K., Darbyshire, A., Sanchez-Moran, E., and Franklin, F. C. H. (2018). TOPII and chromosome movement help remove interlocks between entangled chromosomes during meiosis. J. Cell Biol. 217, 4070-4079. doi: 10.1083/jcb.201803019

Mathur, J., Griffiths, S., Barton, K., and Schattat, M. H. (2012). "Chapter eight - green-to-Red photoconvertible mEosFP-aided live imaging in plants," in Methods in Enzymology Imaging and Spectroscopic Analysis of Living Cells, ed. P. M. Conn (Cambridge, MA: Academic Press), 163-181. doi: 10.1016/B978-012-391857-4.00008-2

Matthies, H. J., McDonald, H. B., Goldstein, L. S., and Theurkauf, W. E. (1996). Anastral meiotic spindle morphogenesis: role of the non-claret disjunctional kinesin-like protein. J. Cell Biol. 134, 455-464. doi: 10.1083/jcb.134. 2.455

Mogessie, B., and Schuh, M. (2017). Actin protects mammalian eggs against chromosome segregation errors. Science 357:eaal1647. doi: 10.1126/science. aal1647

Morgan, C. H., Zhang, H., and Bomblies, K. (2017). Are the effects of elevated temperature on meiotic recombination and thermotolerance linked via the axis and synaptonemal complex? Philos. Trans. R. Soc. Lond. B Biol. Sci. 372:20160470. doi: 10.1098/rstb.2016.0470

Morgan, C., Fozard, J. A., Hartley, M., Henderson, I. R., Bomblies, K., and Howard, M. (2021). Diffusion-mediated HEI10 coarsening can explain meiotic crossover 
positioning in Arabidopsis. Nat. Commun. 12:4674. doi: 10.1038/s41467-02124827-w

Murphy, S. P., Gumber, H. K., Mao, Y., and Bass, H. W. (2014). A dynamic meiotic SUN belt includes the zygotene-stage telomere bouquet and is disrupted in chromosome segregation mutants of maize (Zea mays L.). Front. Plant Sci. 5:314. doi: $10.3389 /$ fpls.2014.00314

Nannas, N. J., Higgins, D. M., and Dawe, R. K. (2016). Anaphase asymmetry and dynamic repositioning of the division plane during maize meiosis. J. Cell Sci. 129, 4014-4024. doi: 10.1242/jcs. 194860

Nikalayevich, E., Bouftas, N., and Wassmann, K. (2018). "Detection of separase activity using a cleavage sensor in live mouse oocytes," in Mouse Oocyte Development: Methods and Protocols Methods in Molecular Biology, eds M.-H. Verlhac and M.-E. Terret (New York, NY: Springer), 99-112. doi: 10.1007/9781-4939-8603-3_11

Okuda, S., Tsutsui, H., Shiina, K., Sprunck, S., Takeuchi, H., Yui, R., et al. (2009). Defensin-like polypeptide LUREs are pollen tube attractants secreted from synergid cells. Nature 458, 357-361. doi: 10.1038/nature07882

Pacini, E., and Cresti, M. (1978). Ultrastructural characteristics of the tapetum and microspore mother cells in Lycopersicum peruvianum during meiotic prophase. Bull. Soc. Bot. Fr. Actual. Bot. 125, 121-128.

Pawlowski, W. P., Grelon, M., and Armstrong, S. (2013). Analyzing meiosis in Barley. Methods Mol. Biol. 990, 135-144. doi: 10.1007/978-1-62703-333-6_14

Pfender, S., Kuznetsov, V., Pasternak, M., Tischer, T., Santhanam, B., and Schuh, M. (2015). Live imaging RNAi screen reveals genes essential for meiosis in mammalian oocytes. Nature 524, 239-242. doi: 10.1038/nature14568

Phillips, D., Jenkins, G., Macaulay, M., Nibau, C., Wnetrzak, J., Fallding, D., et al. (2015). The effect of temperature on the male and female recombination landscape of barley. New Phytol. 208, 421-429. doi: 10.1111/nph.13548

Pradillo, M., and Heckmann, S. eds (2020). Plant Meiosis: Methods and Protocols. New York, NY: Humana Press. doi: 10.1007/978-1-4939-9818-0

Prunet, N., Jack, T. P., and Meyerowitz, E. M. (2016). Live confocal imaging of Arabidopsis flower buds. Dev. Biol. 419, 114-120. doi: 10.1016/j.ydbio.2016.03. 018

Prusicki, M. A., Hamamura, Y., and Schnittger, A. (2020a). "A practical guide to live-cell imaging of meiosis in Arabidopsis," in Plant Meiosis: Methods and Protocols Methods in Molecular Biology, eds M. Pradillo and S. Heckmann (New York, NY: Springer), 3-12. doi: 10.1007/978-1-49399818-0_1

Prusicki, M. A., Keizer, E. M., van Rosmalen, R. P., Komaki, S., Seifert, F., Müller, K., et al. (2019). Live cell imaging of meiosis in Arabidopsis thaliana. eLife 8:e42834. doi: 10.7554/eLife.42834

Prusicki, M., Keizer, E., van Rosmalen, R., Fleck, C., and Schnittger, A. (2020b). Live cell imaging of male meiosis in Arabidopsis by a landmark-based system. Bio Protoc. 10:e3611. doi: 10.21769/BioProtoc.3611

Qin, Y., Zhao, L., Skaggs, M. I., Andreuzza, S., Tsukamoto, T., Panoli, A., et al. (2014). ACTIN-RELATED PROTEIN6 regulates female meiosis by modulating meiotic gene expression in Arabidopsis. Plant Cell 26, 1612-1628. doi: 10.1105/ tpc. 113.120576

Rasmussen, C. G., Wright, A. J., and Müller, S. (2013). The role of the cytoskeleton and associated proteins in determination of the plant cell division plane. Plant J. 75, 258-269. doi: 10.1111/tpj.12177

Reitz, D., Grubb, J., and Bishop, D. K. (2019). A mutant form of Dmc1 that bypasses the requirement for accessory protein Mei5-Sae3 reveals independent activities of Mei5-Sae3 and Rad51 in Dmc1 filament stability. PLoS Genet. 15:e1008217. doi: 10.1371/journal.pgen.1008217

Rockmill, B., Sym, M., Scherthan, H., and Roeder, G. S. (1995). Roles for two RecA homologs in promoting meiotic chromosome synapsis. Genes Dev. 9, 2684-2695. doi: 10.1101/gad.9.21.2684

Rueda, J., and Vázquez, A. M. (1988). Meiotic behaviour of the pollen mother cells in cultured anthers of rye excised at early meiotic prophase. Genome 30, 161-165. doi: 10.1139/g88-028

Ryan, K. (1983). Chromosome movements in pollen mother cells: techniques for living cell cine-microscopy and for electron microscopy. Mikroskopie 40, $67-78$.

Sanchez-Moran, E., Santos, J.-L., Jones, G. H., and Franklin, F. C. H. (2007). ASY1 mediates AtDMC1-dependent interhomolog recombination during meiosis in Arabidopsis. Genes Dev. 21, 2220-2233. doi: 10.1101/gad. 439007
Schuh, M., and Ellenberg, J. (2007). Self-Organization of MTOCs replaces centrosome function during Acentrosomal spindle assembly in live mouse oocytes. Cell 130, 484-498. doi: 10.1016/j.cell.2007.06.025

Schwarzacher, T. (2003). Meiosis, recombination and chromosomes: a review of gene isolation and fluorescent in situ hybridization data in plants. J. Exp. Bot. 54, 11-23. doi: 10.1093/jxb/erg042

Sheehan, M. J., and Pawlowski, W. P. (2009). Live imaging of rapid chromosome movements in meiotic prophase I in maize. Proc. Natl. Acad. Sci. U.S.A. 106, 20989-20994. doi: 10.1073/pnas.0906498106

Silva, M. C. C., Powell, S., Ladstätter, S., Gassler, J., Stocsits, R., Tedeschi, A., et al. (2020). Wapl releases Sccl-cohesin and regulates chromosome structure and segregation in mouse oocytes. J. Cell Biol. 219:e201906100. doi: 10.1083/jcb. 201906100

Sims, J., Copenhaver, G. P., and Schlögelhofer, P. (2019). Meiotic DNA repair in the nucleolus employs a nonhomologous end-joining mechanism. Plant Cell 31, 2259-2275. doi: 10.1105/tpc.19.00367

Sims, J., Schlögelhofer, P., and Kurzbauer, M.-T. (2021). From microscopy to nanoscopy: defining an Arabidopsis thaliana meiotic atlas at the nanometer scale. Front. Plant Sci. 12:672914. doi: 10.3389/fpls.2021.672914

Singh, G., Da Ines, O., Gallego, M. E., and White, C. I. (2017). Analysis of the impact of the absence of RAD51 strand exchange activity in Arabidopsis meiosis. PLoS One 12:e0183006. doi: 10.1371/journal.pone.0183006

Smith, M. G., Simon, V. R., O'Sullivan, H., and Pon, L. A. (1995). Organelle-cytoskeletal interactions: actin mutations inhibit meiosis-dependent mitochondrial rearrangement in the budding yeast Saccharomyces cerevisiae. Mol. Biol. Cell 6, 1381-1396. doi: 10.1091/mbc.6.10.1381

Sofroni, K., Takatsuka, H., Yang, C., Dissmeyer, N., Komaki, S., Hamamura, Y., et al. (2020). CDKD-dependent activation of CDKA;1 controls microtubule dynamics and cytokinesis during meiosis. J. Cell Biol. 219:e201907016. doi: $10.1083 /$ jcb. 201907016

Stefani, A., and Colonna, N. (1996). The influence of temperature on meiosis and microspores development in Dasypyrum villosum (L.) P. Candargy. Cytologia 61, 277-283. doi: 10.1508/cytologia.61.277

Stern, H., and Hotta, Y. (1970). "Chapter 15 culture of meiotic cells for biochemical studies11this work was supported by a grant from the national science foundation (NSF-GB-5173x) and by supplementary assistance from the Institute for Studies in Developmental Biology (USPHS-HD03015 and NSFGB-6476)," in Methods in Cell Biology, ed. D. M. Prescott (Cambridge, MA: Academic Press), 497-513. doi: 10.1016/S0091-679X(08)61761-6

Strasburger, E. (1888). Über Kern-und Zelltheilungen im Pflanzenreiche, nebst einem Anhang über Befruchtung. Jena: Fisher.

Stronghill, P. E., Azimi, W., and Hasenkampf, C. A. (2014). A novel method to follow meiotic progression in Arabidopsis using confocal microscopy and 5-ethynyl-2'-deoxyuridine labeling. Plant Methods 10:33. doi: 10.1186/17464811-10-33

Takegami, M. H., Yoshioka, M., Tanaka, I., and Ito, M. (1981). Characteristics of isolated microsporocytes from Liliaceous plants for studies of the meiotic cell cycle in vitro. Plant Cell Physiol. 22, 1-10. doi: 10.1093/oxfordjournals.pcp. a076135

Taylor, J. H., and McMaster, R. D. (1953). Autoradiographic and microphotometric studies of desoxyribose nucleic acid during microgametogenesis in Lilium longiflorum. Chromosoma 6, 489-521. doi: 10.1007/BF01259951

Tomita, K., and Cooper, J. P. (2007). The telomere bouquet controls the meiotic spindle. Cell 130, 113-126. doi: 10.1016/j.cell.2007.05.024

Valuchova, S., Mikulkova, P., Pecinkova, J., Klimova, J., Krumnikl, M., Bainar, P., et al. (2020). Imaging plant germline differentiation within Arabidopsis flowers by light sheet microscopy. eLife 9:e52546. doi: 10.7554/eLife.52546

Van Beneden, E. (1883). Recherches sur la maturation de l'oeuf, la fecondation et la division cellulaire /par Éduard Van Beneden. Libraire Clemm and G.Massonéditeur. Available online at: https://gallica.bnf.fr/ark: /12148/bpt6k97385454 (accessed May 27, 2021).

Varas, J., Graumann, K., Osman, K., Pradillo, M., Evans, D. E., Santos, J. L., et al. (2015). Absence of SUN1 and SUN2 proteins in Arabidopsis thaliana leads to a delay in meiotic progression and defects in synapsis and recombination. Plant J. 81, 329-346. doi: 10.1111/tpj.12730

Vargas, E., McNally, K. P., Cortes, D. B., Panzica, M. T., Danlasky, B. M., Li, Q., et al. (2019). Spherical spindle shape promotes perpendicular cortical orientation by preventing isometric cortical pulling on both spindle poles during C. 
elegans female meiosis. Development 146:dev178863. doi: 10.1242/dev.17 8863

Vasil, I. K. (1959). Cultivation of excised anthers in vitro - effect of nucleic acids. J. Exp. Bot. 10, 399-408. doi: 10.1093/jxb/10.3.399

Vogler, F., and Sprunck, S. (2015). F-actin forms mobile and unwinding ringshaped structures in germinating Arabidopsis pollen expressing Lifeact. Plant Signal. Behav. 10:e1075684. doi: 10.1080/15592324.2015.1075684

Wang, H., Li, Y., Yang, J., Duan, X., Kalab, P., Sun, S. X., et al. (2020). Symmetry breaking in hydrodynamic forces drives meiotic spindle rotation in mammalian oocytes. Sci. Adv. 6:eaaz5004. doi: 10.1126/sciadv.aaz5004

Wang, Y., and Copenhaver, G. P. (2018). Meiotic recombination: mixing it up in plants. Annu. Rev. Plant Biol. 69, 577-609. doi: 10.1146/annurev-arplant042817-040431

Weijers, D., Dijk, M. F., Vencken, R.-J., Quint, A., Hooykaas, P., and Offringa, R. (2001). An Arabidopsis minute-like phenotype caused by a semi-dominant mutation in a RIBOSOMAL PROTEIN S5 gene. Development 128, 4289-4299.

White, P. R. (1964). The Cultivation of Animal and Plant Cells, 1954th Edn. New York, NY: The Ronald Press Company.

Wijnker, E., and Schnittger, A. (2013). Control of the meiotic cell division program in plants. Plant Reprod. 26, 143-158. doi: 10.1007/s00497-0130223-X

Wilson, J. Y. (1959). Duration of meiosis in relation to temperature. Heredity 13, 263-267. doi: 10.1038/hdy.1959.29

Wozny, M., Schattat, M. H., Mathur, N., Barton, K., and Mathur, J. (2012). Color recovery after photoconversion of $\mathrm{H} 2 \mathrm{~B}:: \mathrm{mE}$ osFP allows detection of increased nuclear DNA content in developing plant cells. Plant Physiol. 158, 95-106. doi: 10.1104/pp.111.187062

Wu, S.-Z., and Bezanilla, M. (2014). Myosin VIII associates with microtubule ends and together with actin plays a role in guiding plant cell division. eLife 3:e03498. doi: $10.7554 /$ eLife.03498

Xu, H., Tong, Z., Ye, Q., Sun, T., Hong, Z., Zhang, L., et al. (2019). Molecular organization of mammalian meiotic chromosome axis revealed by expansion STORM microscopy. Proc. Natl. Acad. Sci. U.S.A. 116, 18423-18428. doi: 10. 1073/pnas. 1902440116

Yang, C., Hamamura, Y., Sofroni, K., Böwer, F., Stolze, S. C., Nakagami, H., et al. (2019). SWITCH 1/DYAD is a WINGS APART-LIKE antagonist that maintains sister chromatid cohesion in meiosis. Nat. Commun. 10:1755. doi: 10.1038/ s41467-019-09759-w

Yang, C., Sofroni, K., Wijnker, E., Hamamura, Y., Carstens, L., Harashima, H., et al. (2020). The Arabidopsis Cdk1/Cdk2 homolog CDKA;1 controls chromosome axis assembly during plant meiosis. EMBO J. 39:e101625. doi: 10.15252/embj. 2019101625
Yokoyama, R., Hirakawa, T., Hayashi, S., Sakamoto, T., and Matsunaga, S. (2016). Dynamics of plant DNA replication based on PCNA visualization. Sci. Rep. 6:29657. doi: 10.1038/srep29657

Yoon, S., Choi, E.-H., Kim, J.-W., and Kim, K. P. (2018). Structured illumination microscopy imaging reveals localization of replication protein A between chromosome lateral elements during mammalian meiosis. Exp. Mol. Med. 50, 1-12. doi: 10.1038/s12276-018-0139-5

Yu, H.-G., Hiatt, E. N., Chan, A., Sweeney, M., and Dawe, R. K. (1997). Neocentromere-mediated chromosome movement in maize. J. Cell Biol. 139, 831-840.

Yu, H.-G., Muszynski, M. G., and Kelly Dawe, R. (1999). The maize homologue of the cell cycle checkpoint protein MAD2 reveals kinetochore substructure and contrasting mitotic and meiotic localization patterns. J. Cell Biol. 145, 425-435.

Zhao, L., He, J., Cai, H., Lin, H., Li, Y., Liu, R., et al. (2014). Comparative expression profiling reveals gene functions in female meiosis and gametophyte development in Arabidopsis. Plant J. 80, 615-628. doi: 10.1111/tpj.12657

Zhao, X., Bramsiepe, J., Durme, M. V., Komaki, S., Prusicki, M. A., Maruyama, D., et al. (2017). RETINOBLASTOMA RELATED1 mediates germline entry in Arabidopsis. Science 356:eaaf6532. doi: 10.1126/science. aaf6532

Zhao, X., Harashima, H., Dissmeyer, N., Pusch, S., Weimer, A. K., Bramsiepe, J., et al. (2012). A general G1/S-Phase cell-cycle control module in the flowering plant Arabidopsis thaliana. PLoS Genet. 8:e1002847. doi: 10.1371/journal.pgen. 1002847

Conflict of Interest: The authors declare that the research was conducted in the absence of any commercial or financial relationships that could be construed as a potential conflict of interest.

Publisher's Note: All claims expressed in this article are solely those of the authors and do not necessarily represent those of their affiliated organizations, or those of the publisher, the editors and the reviewers. Any product that may be evaluated in this article, or claim that may be made by its manufacturer, is not guaranteed or endorsed by the publisher.

Copyright $\odot 2021$ Prusicki, Balboni, Sofroni, Hamamura and Schnittger. This is an open-access article distributed under the terms of the Creative Commons Attribution License (CC BY). The use, distribution or reproduction in other forums is permitted, provided the original author(s) and the copyright owner(s) are credited and that the original publication in this journal is cited, in accordance with accepted academic practice. No use, distribution or reproduction is permitted which does not comply with these terms. 